\title{
THE LATE HALLSTATT AGE BURIALS OF SOUTHERN TRANSDANUBIA AND A MISSING LINK
}

\author{
BENCE SOÓS
}

Magyar Nemzeti Múzeum

Múzeum krt. 14-16, H-1088 Budapest, Hungary

soos.ben94@gmail.com

\begin{abstract}
For almost four decades our knowledge about the Late Hallstatt Age in southern Transdanubia has been fundamentally shaped by two significant sites: the burial ground near Beremend and Szentlorinc. New discoveries in today's Tolna County, however, lead us to revise some of conclusions drawn based on these sites as well as to realise the complex ways how the burial grounds and the communities using them were integrated into different cultural and social relationships of various scales. One of the main questions is how to interpret the differences and similarities between the two sites. In my view, the recently discovered sites near Alsónyék, Paks and Tolna-Mözs provide new insight how to evaluate the above question and what the mortuary practices of the Middle Iron Age population of southern Transdanubia can tell us about the cultural relations of the region's communities.
\end{abstract}

Keywords: Late Hallstatt Age, burial customs, chronology

\section{INTRODUCTION}

It can hardly be an exaggeration that Lajos Márton's words written in 1933, according to which the latest stage of the Hallstatt period in the case of Transdanubia is 'hitherto insufficiently explored' ${ }^{1}$ are still valid today. Although, this also applies for the southern part of the aforementioned region, it is worth underlying that the situation here is much better than, say, in the areas surroundings the Lake Balaton. ${ }^{2}$ Thanks to the seminal papers of Erzsébet Jerem and later works by several other scholars, ${ }^{3}$ the overall cultural picture, its connections to adjacent regions, and the chronological framework of the area between the Mecsek Mountains and the Drava River are relatively well-defined. However, in light of some recently explored sites it seems worthwhile to give a new assessment of the burial customs and chronological considerations of the funerary record (Fig. 1).

\section{IN THE ORDER OF APPEARANCE}

Although the sites of today's Baranya County have been playing a key role in the attempts at describing the cultural outline of the southern part of Transdanubia in the latest stages of the Hallstatt Period (i.e. the $5^{\text {th }}$ and early $4^{\text {th }}$ century), the first significant discoveries took place slightly further to the north, namely in the area of today's Tolna County. Mór Wosinsky's investigations in that area and especially on the Lengyel hillfort and his reports about his results are widely well-known. Among the items he collected we find two types which are of vital impor-

${ }^{1}$ MÁrton 1933, 17

${ }^{2}$ Marton-RegenYe 2005; HoRvÁth 2015; JÁKy 2016
${ }^{3}$ JeREM 1968; JEREM 1973; JEREM 1974; JEREM 1981; PARZINGer 1989; MeTZNER-NeBELSICK 2002; DizDAR 2015. JÁKY 2017. 


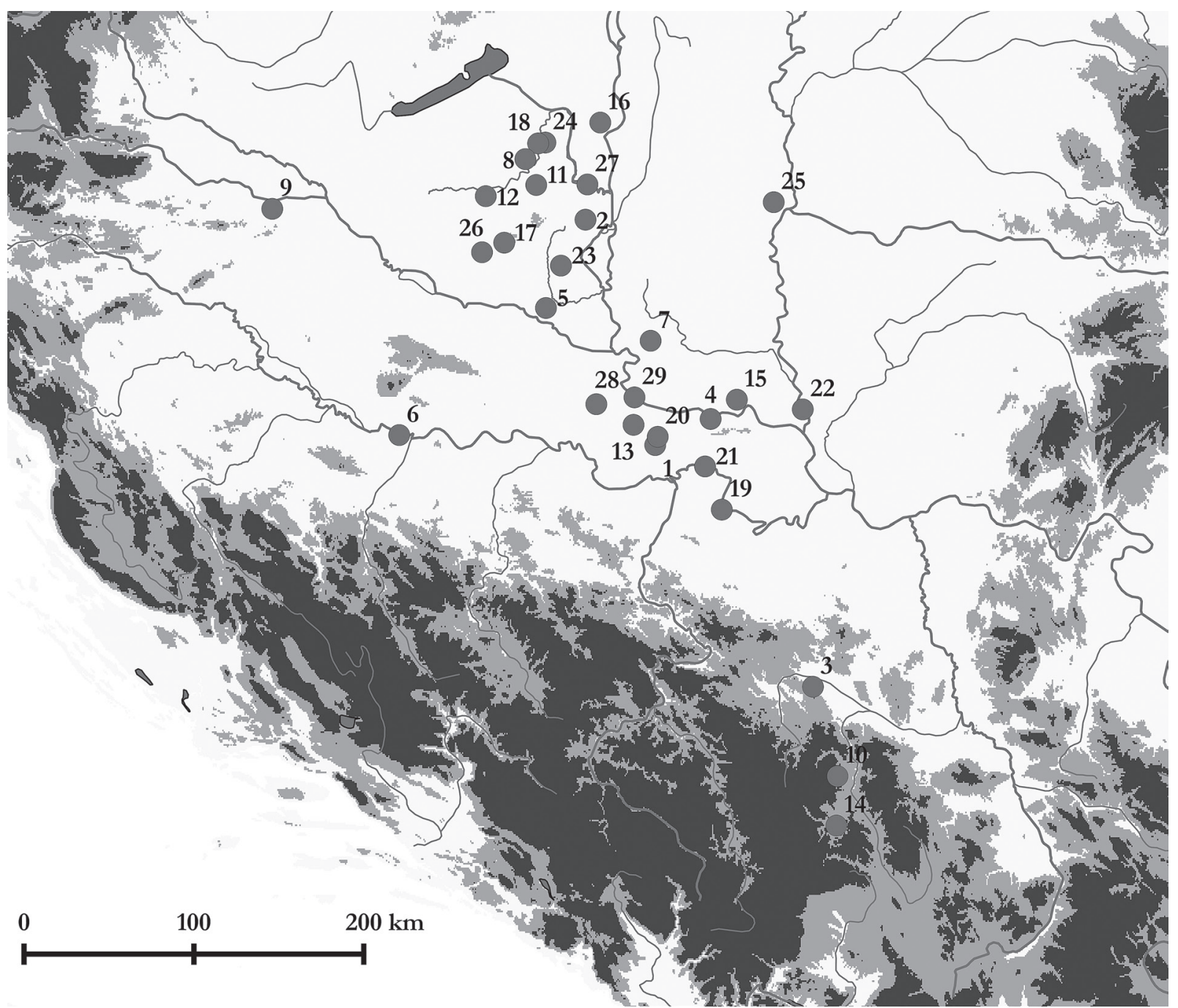

Fig. 1. Map of the sites and locations mentioned in the text. 1: Adaševci; 2: Alsónyék; 3: Atenica; 4: Banoštor; 5: Beremend; 6: Donja Dolina; 7: Dorošlovo-Đepfeld; 8: Gyulaj; 9: Jalžabet; 10: Kruševica; 11: Lengyel; 12: Nagyberki-Szalacska; 13: Novi Banovci; 14: Novi Pazar; 15: Novi Sad; 16: Paks; 17: Pécs-Jakabhegy; 18: Regöly; 19: Šabac; 20: Šid; 21: Srijemska Mitrovica; 22: Stubarlija; 23: Szajk; 24: Szárazd-Gerenyáspuszta; 25: Szeged-Kiskundorozsma; 26: Szentlőrinc; 27: Tolna-Mözs; 28: Vinkovci; 29: Vučedol

tance especially in the light of later discoveries. One of them is an article belonging to a specimen of the so-called astragal type belts. This piece can be assigned to the recently defined Osijek-variant. ${ }^{4}$ On the other hand, he also mentions a Certosa type fibula which, according to the drawing in Wosinsky's monograph, might with confidence be assigned to B. Teržan's $5^{\text {th }}$ variant. ${ }^{5}$ Unfortunately, the exact context of these items is largely unknown for they were discovered as stray finds, however, it seems reasonable to assume that they had not belonged to the burial furniture of a grave. ${ }^{6}$ In light of later discoveries this seems very surprising since the great majority of the specimens of these types have appeared in funerary context. ${ }^{7}$

I have already mentioned that our current knowledge of the later stages of the Hallstatt Age in southern Transdanubia is quite limited, and also, it is mainly confined to burials. Set aside the invaluable example of the settlement excavated near Szajk, ${ }^{8}$ there is no well-documented habitation site in the region yet. Thus, in the follow-

\section{7, Karta 2}

${ }^{4}$ Wosinsky 1888, Taf. 44,346; Filipović-Mladenović

${ }^{5}$ WosinsKy 1888, Taf 46,367.
${ }^{6}$ WOSINSKY 1888, 221

${ }^{7}$ JovanOVić 1998, 55; DizDAR-TONC 2018, 48.

${ }^{8}$ GÁti 2009; GÁti 2014. 
ings I will mainly focus on the funerary data, yet it should be highlighted that these early records mentioned above clearly point to the possibilities of the settlement research in the future.

During the last decades of the $19^{\text {th }}$ century and at the very beginning of the following century, several items and assemblages came to light in the easternmost parts of Slavonia and in the Srem region. One of the most prominent ones among them is the Vučedol find discovered by agricultural workers in 1902. According to the brief description they provided the bronze and iron objects they collected had been lying next to an inhumation burial. ${ }^{9}$ The alleged grave goods include several articles of an astragal belt, four Certosa fibulae of Teržan's $5^{\text {th }}$ variant, huge amount of glass paste beads, as for weaponry, four spearheads and a long one-edged knife also came to light. ${ }^{10} \mathrm{An}$ other noteworthy example is the grave found between Adaševci and Šid. ${ }^{11}$ According to the account of M. Hoernes, during the construction of a road between the aforementioned villages the workers came across an inhumation burial with a rich collection of bronze adornments (two fibulae, astragal belt) and iron weapons (two spearheads). J. Brunšmid made a thorough assessment of these finds, discovered before 1902. Due to the geographical proximity, and to the cultural links of the region in the Late Bronze and Early Hallstatt Age described in detail by C. MetznerNebelsick in her seminal monograph, it is hardly surprising that similar burials began to appear in the southern part of Transdanubia. The first example, the burial of Szárazd-Gerenyáspuszta, however, is somewhat peculiar in terms of its geographical position. The grave found also by chance in 1930 was located surprisingly far to the north from Slavonia and the Srem region and relatively close to the sites of M. Wosinsky's discoveries. According to the report of L. Márton the burial came to light from a hillside near the banks of the River Kapos, between the well-known prehistoric site Regöly and the modern village Szárazd, ${ }^{12}$ at some $140 \mathrm{~km}$ distance from Vučedol. However, in spite of the distance the assemblage found in this grave resembles by and large the ones published by J. Brunšmid. The characteristic types are all present, such as the astragal belt, the Certosa fibulae of type 5 according to B. Teržan's classification, furthermore, two east Alpine animal-headed fibulae and more than 20 pieces of glass paste beads (Fig. 2). Moreover, the basic characteristics of the burial rite to the extent they were documented show unquestionable similarities, e.g. this burial was also an inhumation..$^{13}$ Unfortunately, the burial from Szárazd remained unparalleled in South Transdanubia until 1973 . This might be a reason why relatively modest attention was paid to this particular grave and to the region north of the River Drava in the most important contributions to the period of what is nowadays more and more frequently called the Middle Iron Age ${ }^{14}$ in Pannonia, for instance the chronological assessment written by Z. Vinski and K. Vinski-Gasparini (1962) and M. Garašanin's seminal monograph (1973).

This situation was radically altered by the graves unearthed near Beremend. In 1962 Iron Age items came to light during sand exploitation, and after their arrival the archaeologists of the Janus Pannonius Museum managed to document two distinct grave assemblages and to mark their positions based on the workers' account. According to the record the burials similarly to the ones unearthed south of the Drava were inhumations and were lying in two separate, yet closely situated grave pits. ${ }^{15}$ As for the items, the artefact types mentioned above were all present. One instance of an astragal belt comes from grave 1 along with two Certosa fibulae of Teržan's $1 \mathrm{~b}$ and 13a variants and with a vast amount of glass paste beads of various colours (Fig. 3.A). On the other hand, the Certosa 5 type is also present among the adornments of the person in Grave 2 (Fig. 3.B) ${ }^{16}$ In spite of their unquestionable similarities, however, the composition of the grave goods in this case shows a more complex picture than that of the assemblages in the graves from Slavonia and the Srem region. There are several artefacts among the grave goods of the second grave, whose analogies are not yet to be found among the material from the aforementioned regions. To begin with, there is a composite belt with openwork decoration among the items (Fig. 3.4). The belt's closest parallel has been unearthed in the Donja dolina cemetery, ${ }^{17}$ however, the great majority of the examples of this type come from the central parts of the Balkans, also from today's Bulgaria and Greece. ${ }^{18}$ Interestingly, this specimen seems to be one of the latest example of the type, since the grave itself has been dated to the end of the $6^{\text {th }}$ century $\mathrm{BC}$, or to the early

\footnotetext{
${ }^{9}$ According to the recent suggestion of M. Dizdar, it seems more likely that the items were associated with two individuals or even two distinct burials (DIZDAR-TONC 2018, 48).

${ }^{10}$ BRUNŠMID 1902, 68-70.

${ }^{11}$ HoERnes 1901, 282-284.

${ }^{12}$ Márton 1933, 17.

${ }^{13}$ Based on the finder's account. The document is accessible in the Archives of the Hungarian National Museum (Call no. 35.Gy.1.)
}

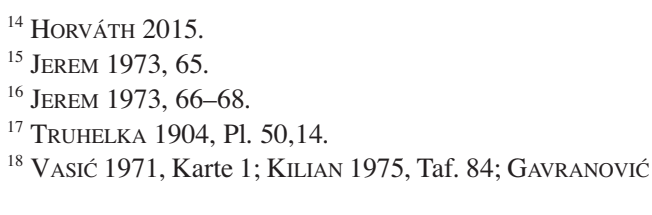
$2011,220$.

Acta Archaeologica Academiae Scientiarum Hungaricae 71, 2020 

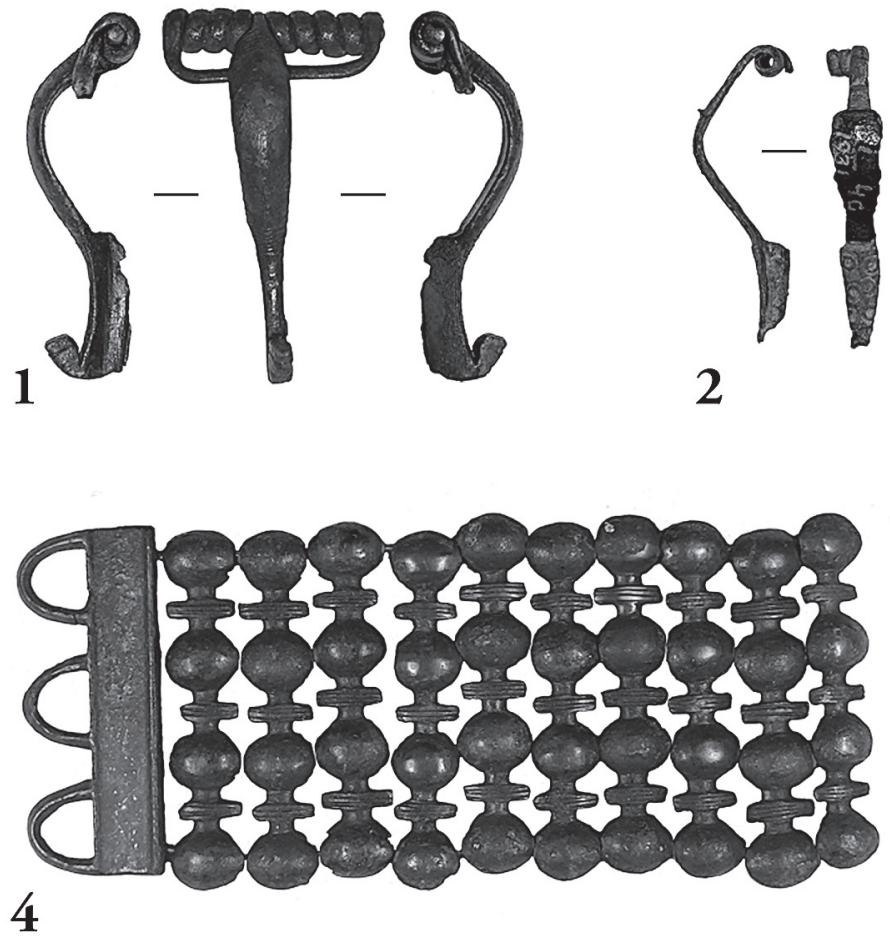

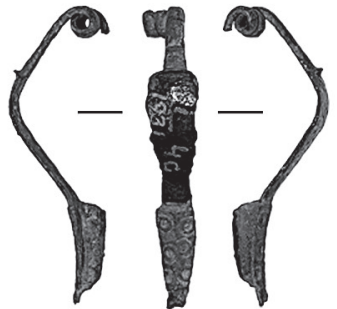

2

3
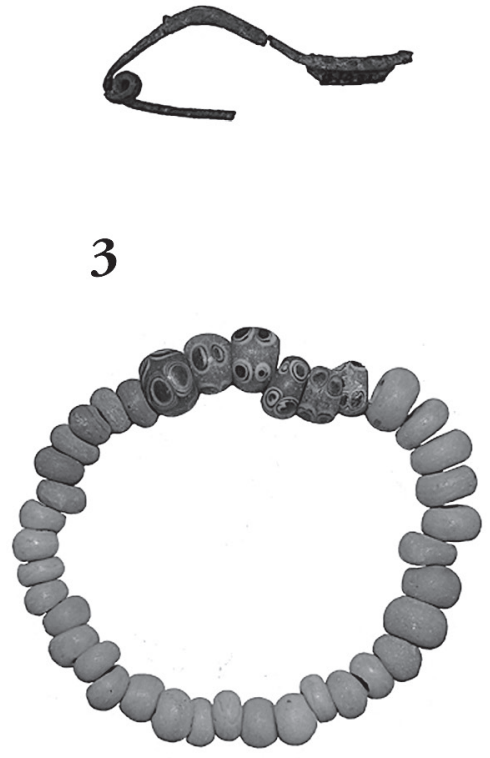

5

Fig. 2. Grave goods found in the Middle Iron Age burial near Szárazd-Gerenyáspuszta

decades of the $5^{\text {th }}$ century. ${ }^{19}$ Another noteworthy item from Grave 2 is a tubular rod made of bronze sheet commonly referred to as a sceptre (Fig. 3.8). ${ }^{20}$ Their main distribution area covers today's Slovenia and northern Italy, and they appear rather seldom to the east of the aforementioned regions. ${ }^{21}$ Their occurrence in the southern part of Transdanubia strongly suggests that the communities living on the northern hinterland of the Drava River were integrated into a system of communication with the catchment areas of the upper Sava and Drava. ${ }^{22}$ Finally, a few words ought to be devoted to the silver fibulae of the Novi Pazar type found also in Grave 2 (Fig. 3.9-10). As its name makes it obvious, this type and especially its specimens made of precious metal are closely linked to the material of one of the most prominent princely graves of the Central Balkans, however, this form also became a common and fashionable piece of attire in the Balkans, and even in the Srem region during the late Hallstatt period. ${ }^{23}$ Similar significance might be assigned to the silver bead found among the pieces of attire in Grave $1 .{ }^{24}$ Due to their presence in the ostentatious assemblages, e.g. Novi Pazar, ${ }^{25}$ Atenica ${ }^{26}$ and Kruševica, ${ }^{27}$ the silver fibulae played a key role in determining the chronological context of the Beremend graves. ${ }^{28}$

The complex character of the material from Beremend becomes even more apparent when we look at the collection of stray finds found at this very site. Numerous Certosa fibulae, animal-headed fibulae, a sceptre and jug with a horn-handle testify to the strong cultural links of the region under discussion with the so-called Dolenjska group in the early $5^{\text {th }}$ century. ${ }^{29}$

${ }^{19}$ TERŽAN 1990,159; MetZner-Nebelsick 2002, 418; PotrebiCA-Dizdar 2014a, 154.

${ }^{20}$ JEREM 1973, Abb. 7.1; JEREM 1974, 234-236.

${ }^{21}$ JeREM 1974, 236; TeCCO HVAla 2012, 338.

${ }^{22}$ JEREM 1973, 85; JEREM 1974, 238; MAJNARIĆ-PANDŽIĆ $2003,490$.

${ }^{23}$ VASIĆ 1987b; VASIĆ 1999, 79-80; DIZDAR 2019, 329.

${ }^{24}$ ПаЛАвеСтРА 1984, 67; РотREвICA-DizdAR 2014a, 156.
${ }^{25}$ Mano-Zisi-Popović 1971, Taf. 82-83.

${ }^{26}$ Duuknić-Jovanović 1965, Taf. 9,9, 15,13.

${ }^{27}$ СРЕЈОВИЋ-ВУКАДИН 1988, 9.

${ }^{28}$ JEREM 1973, 84; GuŠTiN-TERŽAN 1976, Sl. 4; GUŠTINTERŽAn 1977, 80; METZNER-NEBElSick 2002, 418; PARZINGER 1989, 106, PotrebiCA-Dizdar 2014a, 154.

${ }^{29}$ Dular 1982, 224; MetZner-Nebelsick 2002, 178; Potrebica 2003, 225. 


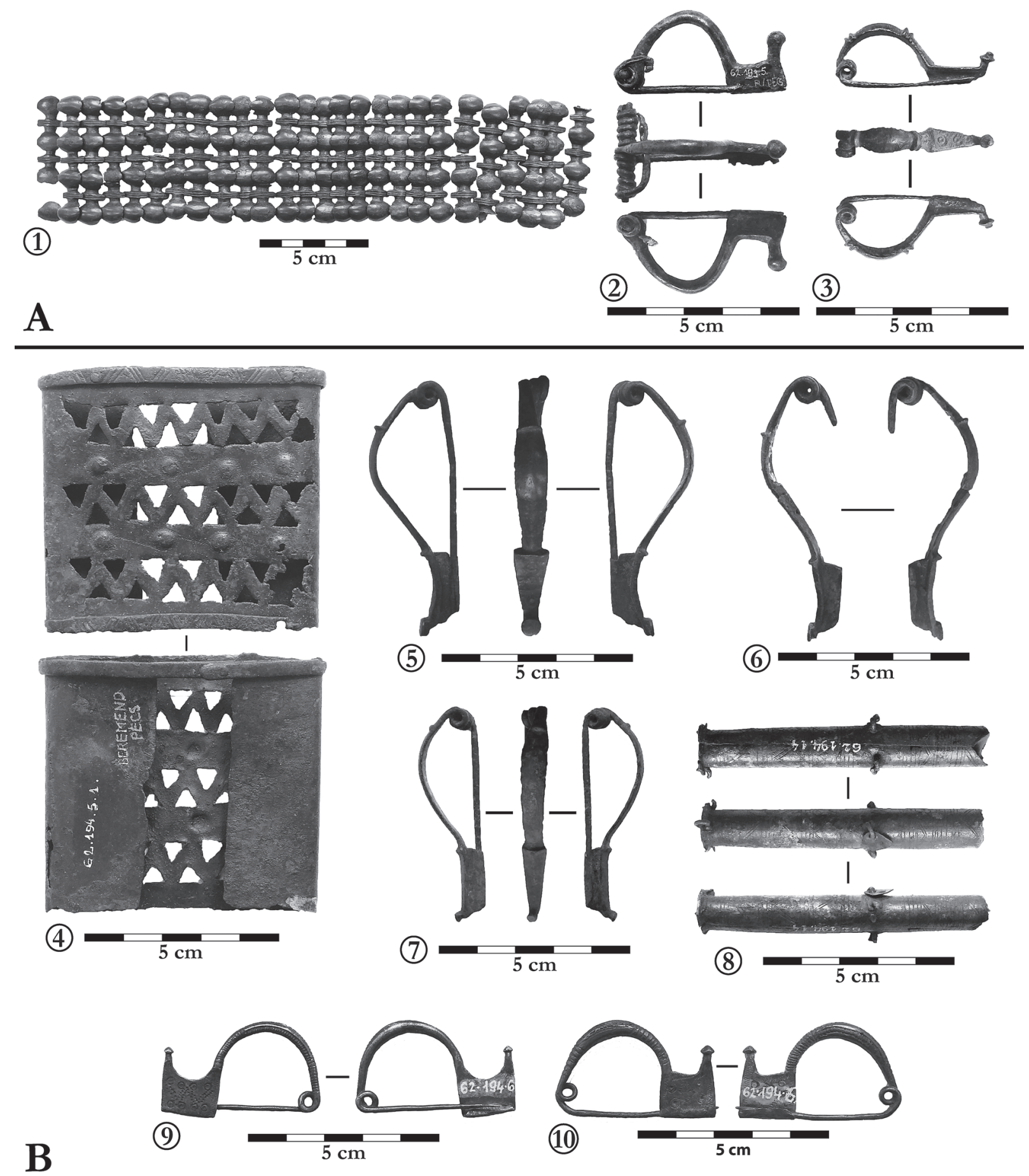

Fig. 3. Selected grave goods of the Beremend burials. A: Grave 1; B: Grave 2 
After the discovery near Beremend for more than 30 years, no comparable burials came to light. In 1995, however, near Tolna-Mözs a few burials were uncovered during the rescue excavation preceding the construction works of the M9 motorway. According to the preliminary reports of Attila Gaál there was a burial with unexpectedly rich grave furniture. Among these items we find the usual elements of attire, i.e. astragal belts, glass paste beads, and Certosa fibulae..$^{30}$ These were complemented by four gold and amber beads, thus this grave became the best comparison to Grave 1 of the Beremend graveyard, however, in this case it was possible to fully document the burial and the exact positions of the adornments within the grave, as a result, the archaeologists managed to fully document the way the belt had been worn. In addition to this grave - also the burial discovered near Paks-Gyapa underlines the quickly growing importance of today's Tolna County's area in the research of the Middle Iron Age of southern Transdanubia. Similarly to the one discovered near Tolna-Mözs the Paks grave was well-documented during the rescue excavation preceding the construction works of the M6 highway. The grave goods included an astragal belt, an iron knife and several glass paste beads, items that are almost omnipresent, however, this burial show traits shared by none of the others mentioned above. For instance, the high number of Certosa 13 type fibulae and their typological variety should be highlighted.

Based on this overview, seemingly, a certain pattern emerges which is to a large extent followed by an extensive proportion of the burials assigned to the Srem group. One of the most obvious characteristics they have in common is the rich composition of the grave goods including Certosa fibulae and astragal belts highlighted by several authors. ${ }^{31}$ Of course, this is rather simplistic and there are obvious variations in the composition, and the social relationships encoded in the patterns of the burial furniture's composition needs exploring in more detail in order to be able obtain a deeper understanding of the social structures of the population in the southern Pannonian region, but due to the insufficient amount of data this is hardly possible at this point. Suffices to say, that in spite of a certain variability the graves discussed above show undeniable similarities and even some kind of standardization considering the grave equipment's composition.

Another unquestionable similarity shared by the graves is the inhumation burial rite. Several scholars acknowledge the overall prominence of this form of burial in the period under discussion, ${ }^{32}$ and in the case of the Srem group some of them even claimed its exclusivity among the funerary customs in this age. ${ }^{33}$ In addition to the fact that most of the graves contained an inhumation, the position of the deceased in the grave pits also tends to be quite similar, i.e. the individuals chiefly lied in supine position. This has been recorded in the case of the Tolna-Mözs burial, ${ }^{34}$ in the case of the graves found at Stubarlija ${ }^{35}$ and in the case of Grave 18 at Doroslovo-Đepfeld ${ }^{36}$ just to name a few examples.

One of the most remarkable and hitherto undiscussed similarity arises when we look at the graves' natural settings. In 1827 the Drava River breached the dyke system that recently had been created at several points causing its largest flooding in the $19^{\text {th }}$ century. ${ }^{37}$ The river inundated its entire floodplain and reached the environs of Beremend. ${ }^{38}$ If we look at the maps of the Josephinian Land Survey of the Habsburg Empire (1763-1787), it is clearly visible that the areas lying to the south of Beremend were regularly inundated. (Fig. 4) The Iron Age cemetery, however, seems to be situated exactly along the edge of a slight elevation that must have remained dry even in the case of the most formidable floods. The Szárazd grave presents a very similar situation. Although we do not know exactly where the burial was located, L. Márton mentions that it was found on a hillside near a creek close to the hamlet Gerenyáspuszta between the modern villages Szárazd and Gyönk. ${ }^{39}$ Based on this information we might be able to confine the exact location of the grave to a certain are marked on the map below (Fig. 5). Not surprisingly, according to this the grave must have been situated in very close proximity (according to Márton: 'on the edge of a gully ${ }^{40}$ ) to the area regularly covered by the water of the Kapos River and its tributary the Koppány creek, creating an extensive marshland just adjacent to the presumable location of the grave. ${ }^{41}$ The Tolna-Mözs site discovered

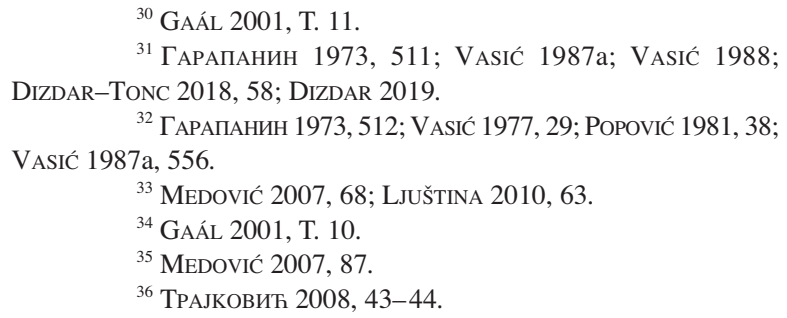

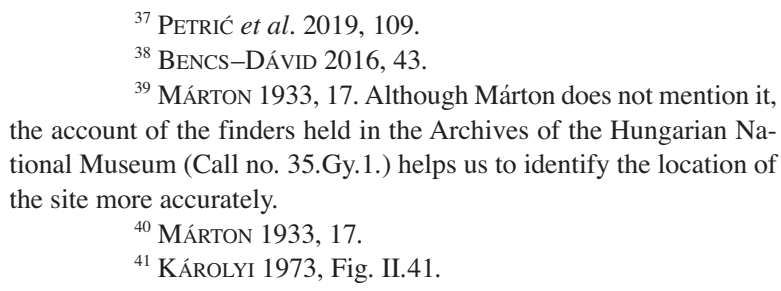

${ }^{39}$ MÁRTOn 1933, 17. Although Márton does not mention it, the account of the finders held in the Archives of the Hungarian National Museum (Call no. 35.Gy.1.) helps us to identify the location of the site more accurately.

${ }^{40}$ MÁrton 1933, 17.

${ }^{41}$ KÁrolyi 1973, Fig. II.41. 


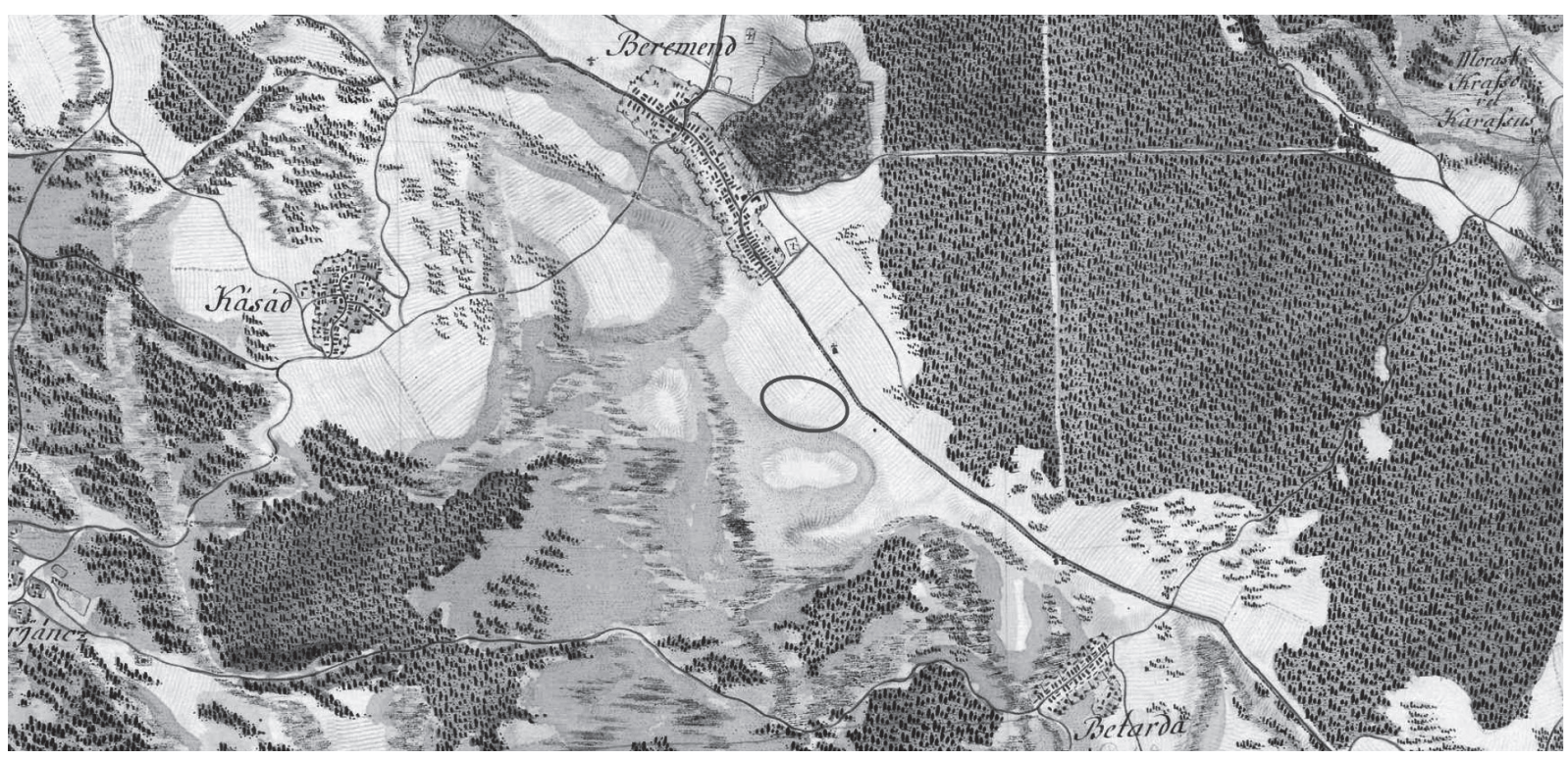

Fig. 4. The environs of Beremend site on the First Military Survey of the Habsburg Empire (Source: https://mapire.eu/hu/map/firstsurvey-hungary/ (Access: 2019.12.29)

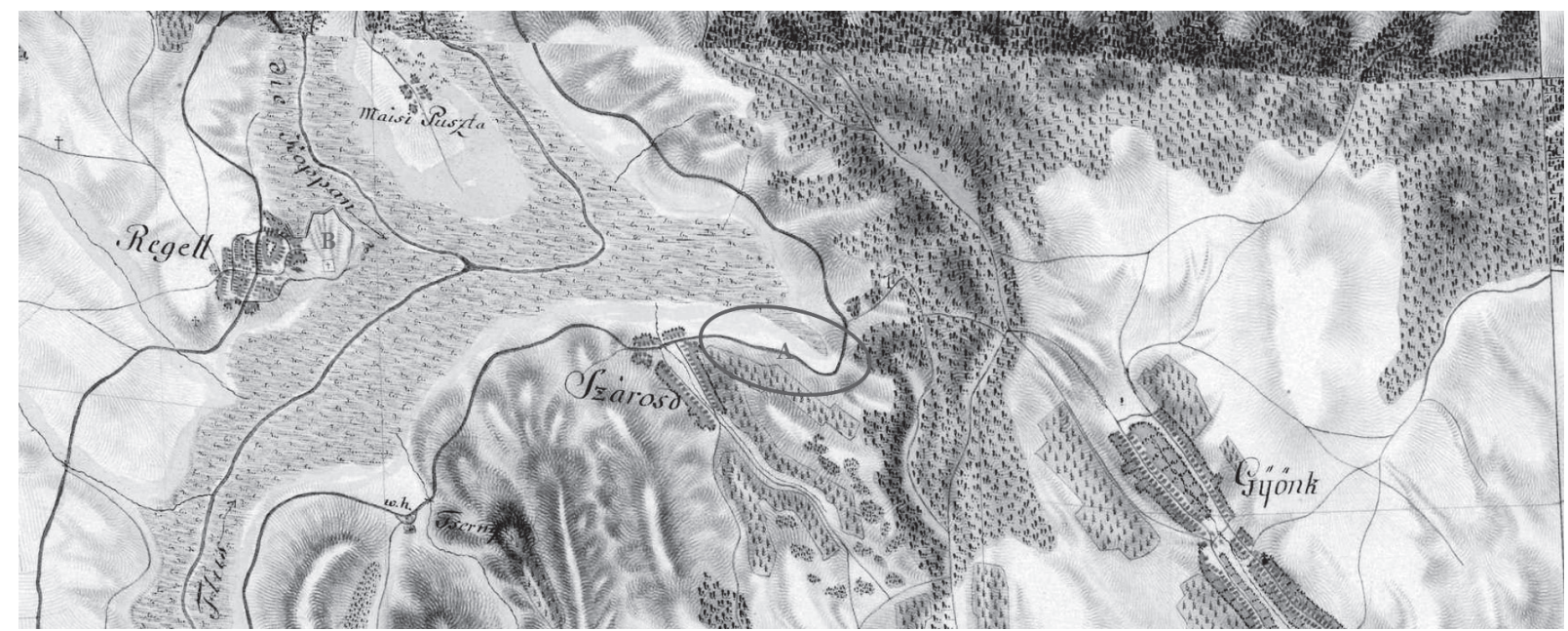

Fig. 5. The environs of Szárazd site on the First Military Survey of the Habsburg Empire.

A: the presumable location of the Szárazd-Gerenyáspuszta grave; B: the prehistoric fortified settlement of Regöly

(Source: https://mapire.eu/hu/map/firstsurvey-hungary/ (Access: 2019.12.29)

between the Sárvíz creek and the Danube River follows the same pattern. According to the maps of the First Military Survey of the Habsburg Empire the site used to be adjacent to the floodplains of the aforementioned waterways and the marshlands created by them located to the south, however, it seems that the area of the site situated on a slight elevation that supposedly remained dry during the whole year (Fig. 6). ${ }^{42}$ On the other hand, however, there is an exception to the pattern. The Paks-Gyapa site, although situated relatively close to the Danube River, is not quite adjacent to either floodplains or marshes, only a minor creek able to inundate certain parts of the landscape might be mentioned here (Fig. 7). In addition to the Transdanubian examples, nonetheless, there are a number of instances of the pattern beyond the region under discussion. ${ }^{43}$

${ }^{42}$ KÁrolyi 1973, Fig. II.45.

${ }^{43}$ Just to name a few: Vučedol (BRUNŠMID 1902); VinkovciSilos (MAJNARIĆ-PANDŽIĆ 2003, Abb. 13); Šabac-Donjošorsko
(ВАСиљЕвић 1976, 170-173); Srijemska-Mitrovica-Fabrika tanina (BRUNŠMID 1902, 75) 


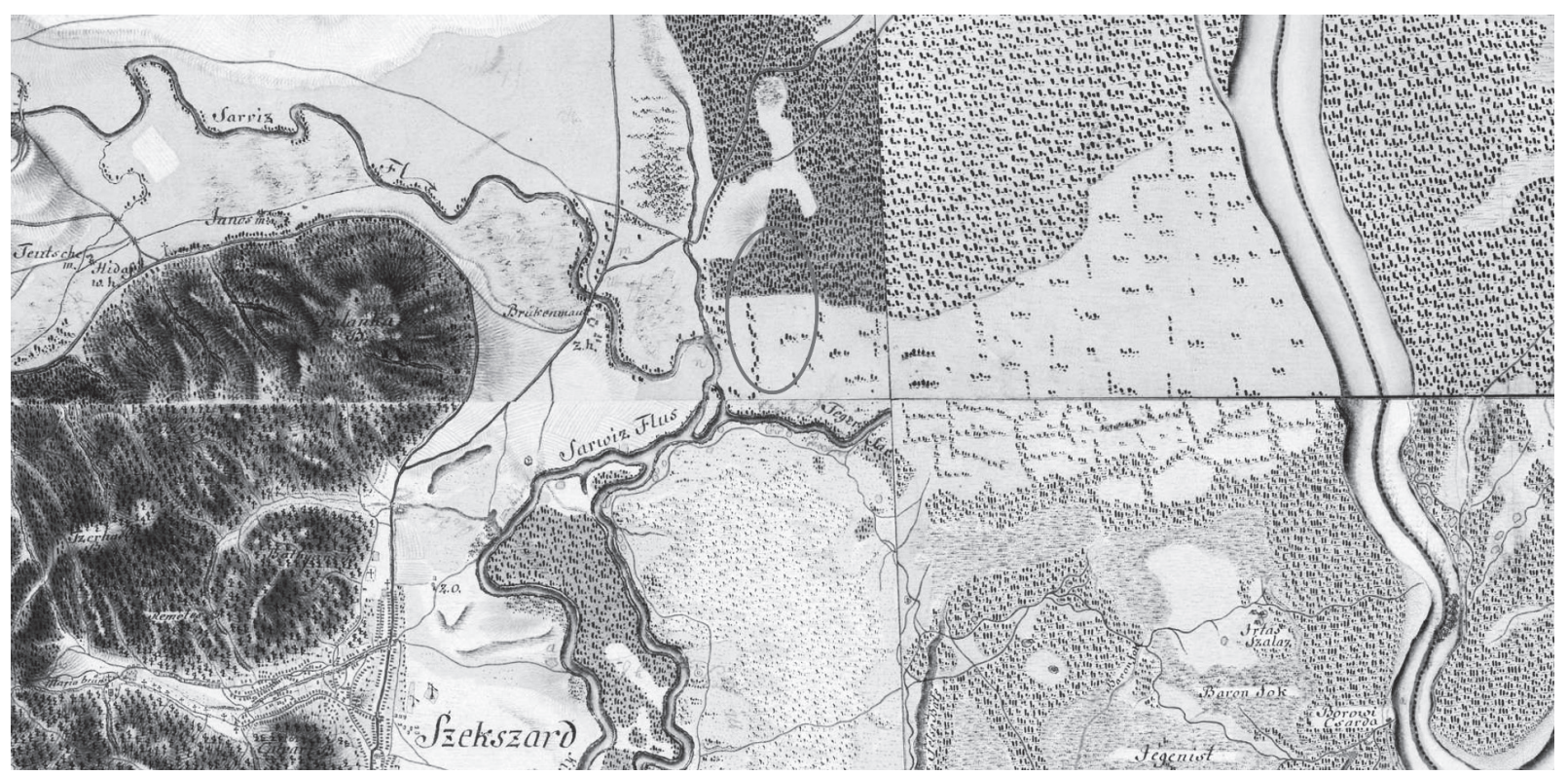

Fig. 6. The environs of the cemetery near Tolna-Mözs on the First Military Survey of the Habsburg Empire (Source: https://mapire.eu/hu/map/firstsurvey-hungary/ (Access: 2019.12.29)

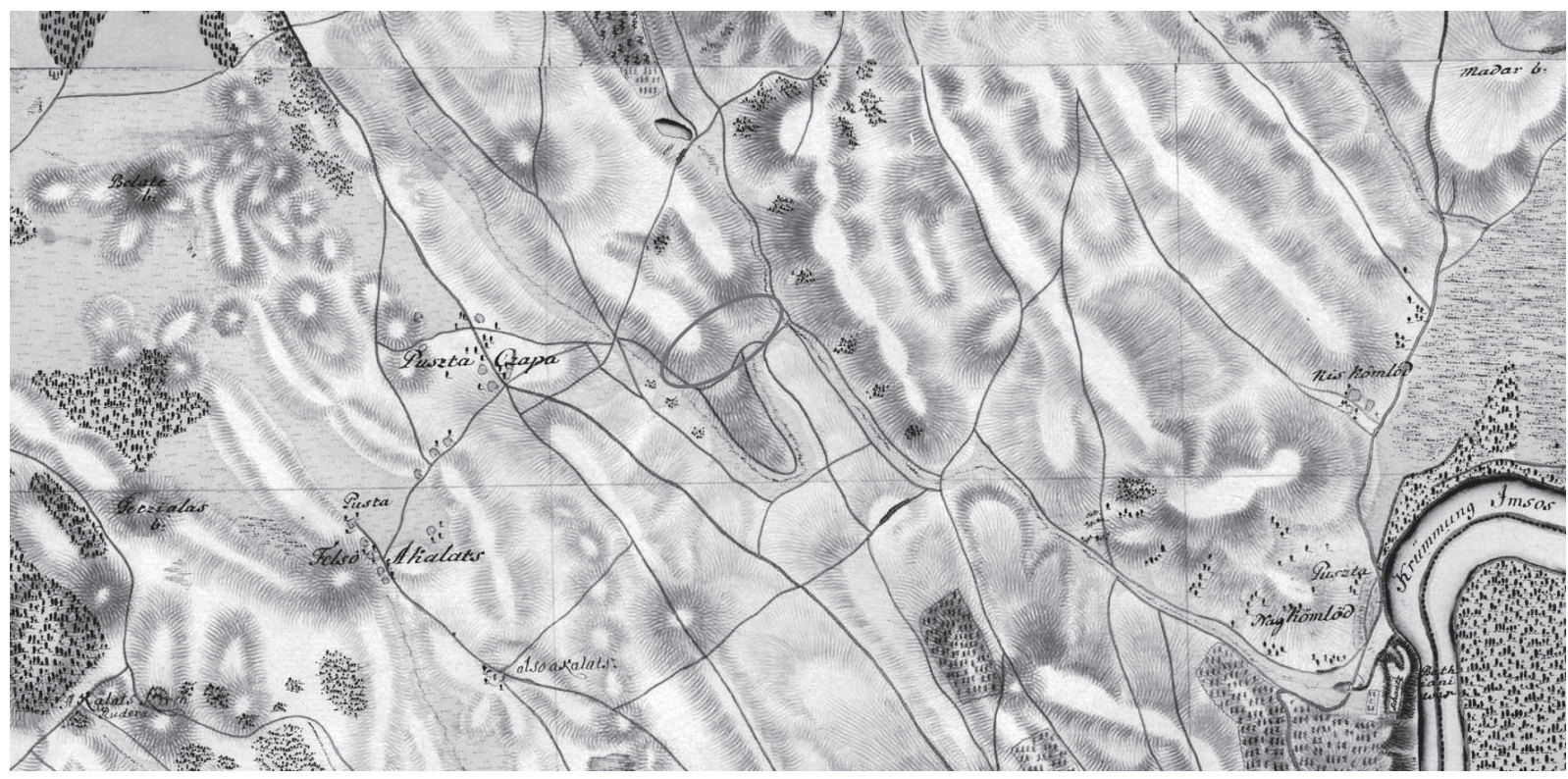

Fig. 7. The environs of the Paks-Gyapa site on the First Military Survey of the Habsburg Empire

(Source: https://mapire.eu/hu/map/firstsurvey-hungary/ (Access: 2019.12.29))

And finally, the aforementioned graves also have a somewhat peculiar characteristic in a common. Although the circumstances of the Szárazd grave's discovery are largely undocumented, Nándor Fettich and L. Márton, archaeologists of the Hungarian National Museum were familiar with the exact location ${ }^{44}$ of the grave and were able to conduct an excavation of relatively small extent, but were unable to find further burials. ${ }^{45}$ E. Jerem writes about a similar situation, i.e. after workers of the sand quarry near Beremend had come across the remains of the

${ }^{44}$ Tolnamegyei Ujság 12/99 (1930) 3; the reports of N. Fettich and L. Márton are accessible in the archives of the Hungarian National Museum (Call no. 1930/139; 35.Gy.1.)
${ }^{45}$ The Archives of the Hungarian National Museum: Call no. $1930 / 139 ; 35 . G y .1$

Acta Archaeologica Academiae Scientiarum Hungaricae 71, 2020 


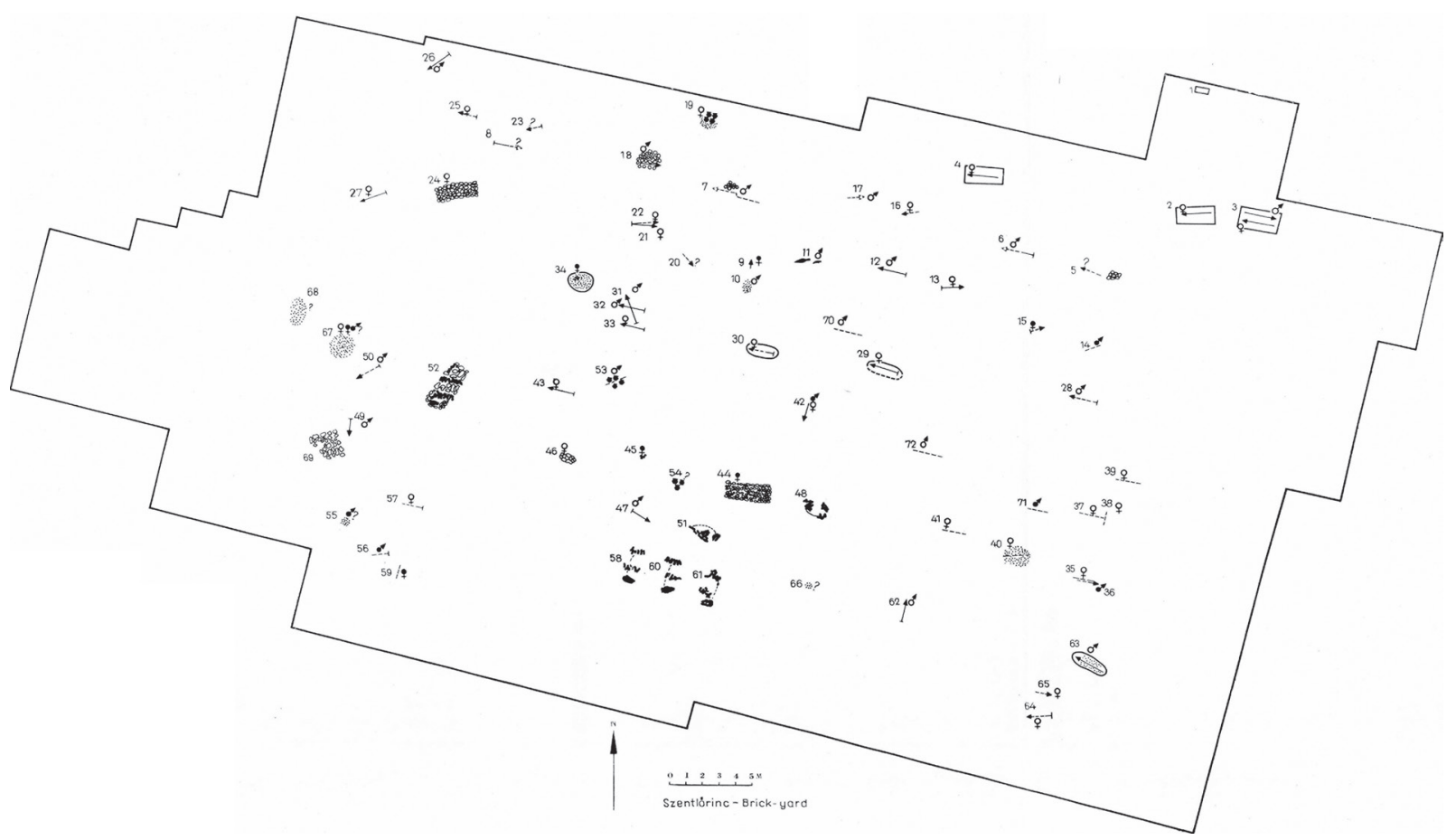

Fig. 8. The layout of the Szentlörinc cemetery (after JEREM 1968, Fig. 2)

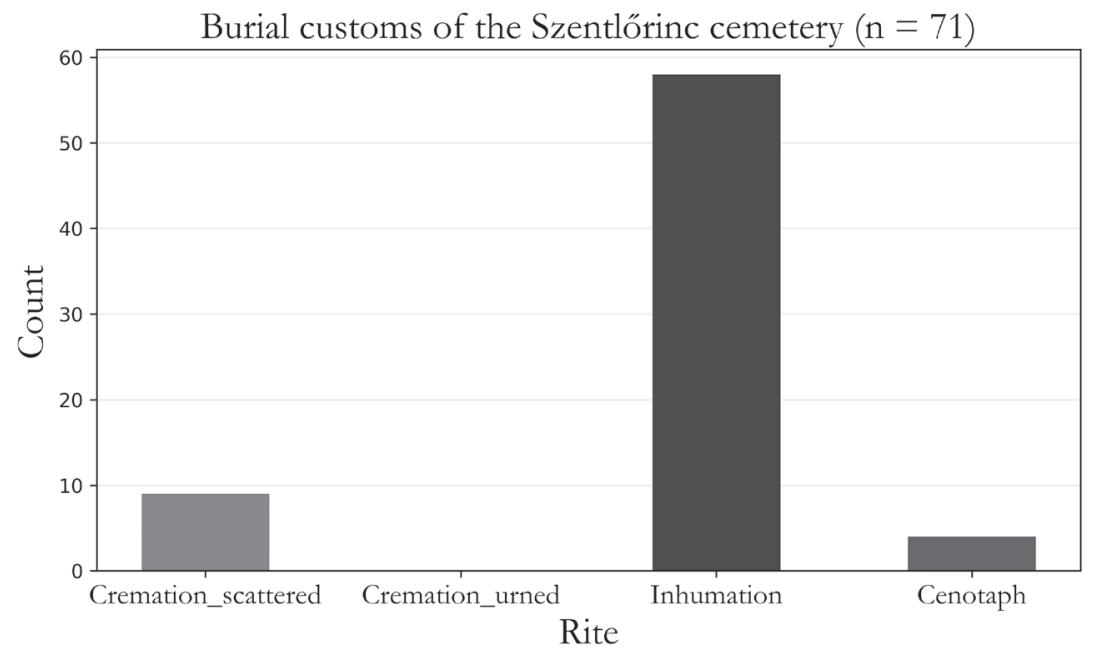

Fig. 9. Burial customs in the Szentlörinc cemetery

Another noteworthy difference might be the fact that there is no grave in the Szentlörinc cemetery whose grave goods would show such richness in composition as those of the previously discussed burials do. And there are several cases of completely missing grave furnishing, whose cause might be plunder but the possibility cannot be ruled out, that originally no grave goods had been placed next to the deceased. Another notable difference is that the graves of the Szentlorinc cemetery have significantly fewer glass paste beads than those of the 'Beremend-type' (Fig. 10). It is also readily apparent that Certosa 5 type fibulae and astragal belts are entirely absent from the material. And even though in the first case this might be explained with a presumable chronological difference, but in 


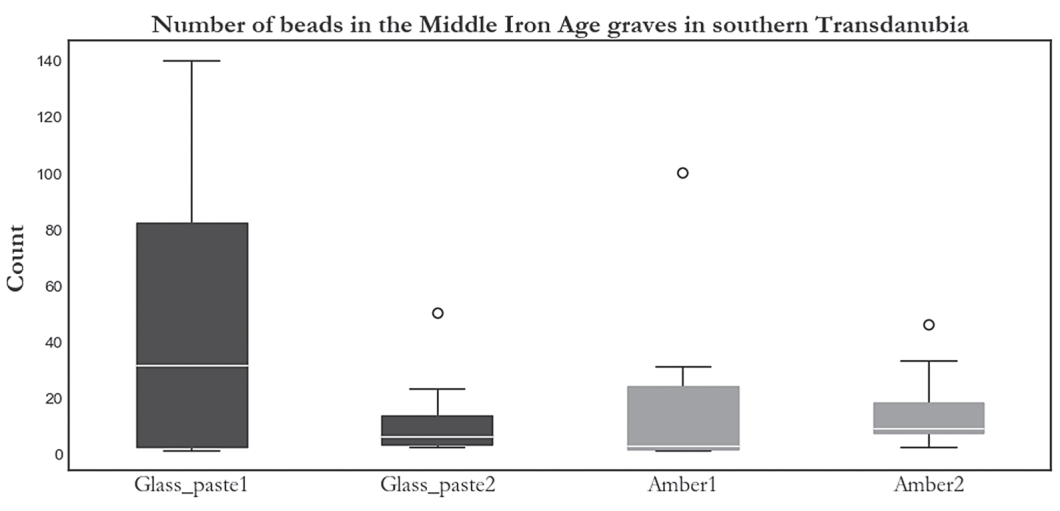

Fig. 10. The number of beads in graves in southern Transdanubia

the case of the latter elements of attire this is hardly possible. It should be also highlighted that while bronze items tend to be rather scarce in this cemetery, ceramic objects are seen in an unprecedented amount. In addition, set aside the biconical silver beads ${ }^{57}$ from Grave 41 and 44 contrary to the case of for instance Beremend or Srijemska Mitrovica $^{58}$ items that might be directly linked to the so-called princely graves in the central Balkans are also missing.

When addressing the social and economic aspects of the burials with opulent grave goods in the Middle Iron Age in the Srem region, S. Babić and A. Palavestra considered two possibilities: either the overall society was relatively wealthy, or - which is just more likely - the burials of the representatives of the lower strata simply had not been found or identified. ${ }^{59}$ Now, the Szentlörinc cemetery seems like an adequate example for dissolving this problem, but the fact is that there are some chronological considerations which do not allow reaching an easy conclusion.

\section{CHRONOLOGY}

Up until this point, the chronological framework of the graves has hardly been touched upon. But as it turns out the most-widely discussed distinction between the previously discussed graves and the Szentorrinc cemetery is of chronological nature. Firstly, M. Guštin and B. Teržan brought attention to the fact that the most significant sites of the Middle Iron Age in Transdanubia, i.e. Beremend and Szentlorrinc can be assigned to chronological phases corresponding by and large to the Certosa- and Negova-phases of the Dolenjska group in today's Slovenia, respectively. ${ }^{60}$

In fact, they were the ones who firstly dated Grave 2 of Beremend slightly earlier than E. Jerem did. ${ }^{61}$ They were the first but not the last. Since then several authors claimed that this burial should be seen as an evidence that the characteristic items of the Certosa phase's material in Slovenia might have already appeared in the southeaster part of Transdanubia at the end of the $6^{\text {th }}$ century BC, or at the very beginning of the next century. ${ }^{62}$

The two-phase framework suggested by Guštin and Teržan is in some ways quite similar to the relative chronology of the Srem group developed by M. Garašanin and later refined as well as supplemented by R. Vasić. ${ }^{63}$ Not surprisingly, after the discovery of the Vinkovci cemetery N. Majnarić-Pandžić noticed the correspondence between the two frameworks and suggested that the two phases represented by the Beremend and Szentlorrinc sites might be brought in line with the chronological phases of the Srem group. ${ }^{64}$ Recently, Csilla Gáti highlighted how well Beremend and Szentlörinc fit into the chronological framework of the Srem group. ${ }^{65}$

${ }^{57}$ JEREM 1968, 186; DizDAR-PotrebiCA 2014a, 154

${ }^{58}$ ПАЛАВЕСТРА 1984, 66-67.

${ }^{59}$ BABIĆ-PALAVESTRA 1999, 30.

${ }^{60}$ GuŠTIN-TERŽAn 1977a, S1. 4.

${ }^{61}$ Jerem suggested that the burial is from the $5^{\text {th }}$ century BC (JEREM 1973, 84). In a contrast, the two Slovenian scholars spoke for the possibility that it might even be dated to the latest decades of the $6^{\text {th }}$ century (GUŠTIN-TERŽAN 1977a, S1. 4; GUŠTIN-TERŽAN 1977, 80).
${ }^{62}$ ПалАвеСтPA 1984, 67; PARZinger 1989, 124; MetZNERNeBelsick 2002, 418; PotrebiCA-Dizdar 2014a, 154.

${ }^{63}$ ГАРАПАНИН 1973, 514; VASIĆ 1987a, 557-558; VASIĆ 1989

${ }^{64}$ MAJNARIĆ-PANDŽIĆ 2000, 30; MAJNARIĆ-PANDŽIĆ 2003, 500.

\footnotetext{
${ }^{65}$ GÁtI 2014, 116.
} 
On the other hand, however, there are scholars who suggested alternative relative chronologies. In his transregional chronological analysis H. Parzinger assigned the Middle Iron Age burials of Transdanubia to the $8^{\text {th }}-10^{\text {th }}$ horizons, but the basic idea that the Beremend graves are clearly older than those of the Szentloninc cemetery appears here, too. ${ }^{66}$ Most recently, M. Dizdar developed a well-outlined chronological framework ${ }^{67}$ for the so-called south-Pannonian late Hallstatt group (or as he calls it the Osijek group) a very well-founded concept originally suggested by M. Guštin and B. Teržan ${ }^{68}$ which incorporates the south Transdanubian sites as well as the Srem group. In his paper he argues that the 'Beremend-type' graves are separable in chronological terms from the Szentlörinc cemetery ${ }^{69}$ Hence, it seems that there is a wide agreement among the scholars that the Beremend graves and the Szentlörinc cemetery have proved to represent distinct phases within the Late Hallstatt Age of Transdanubia. This is hardly surprising given the early dates of the Beremend burials put forward by the academic community. Now, the question emerges whether such clear-cut chronological separation between the Szentlörinc cemetery and the rest of the 'Beremend-type' burials in Transdanubia, e.g. the graves found near Szárazd, Tolna or Paks, might be proven. But before I address this question in more detail let us turn back to the Beremend site, because it is of vital importance in answering the above question. As already E. Jerem pointed out based on the numerous stray finds from the site, the Beremend cemetery must have been used even in the later stages of the $5^{\text {th }}$ century BC and possibly even at the beginning of the $4^{\text {th }}$ century. ${ }^{70}$ Although, the absolute dates she proposed seem a bit low, the point she made is essential. Recently, Miklós Szabó has brought attention to this. In his view, this younger horizon of the cemetery is represented mainly by the crossbow fibulae of the Certosa type and the east Alpine animal-headed fibulae among the stray finds. Due to the fact that these items are present among the grave goods of the Paks-Gyapa burial, he argued that this grave might be in fact coeval with this later stage of the Beremend site. ${ }^{71}$ East Alpine animal-headed fibulae are one of the key types of the $9^{\text {th }}$ horizon in H. Parzinger's chronological framework, ${ }^{72}$ and as such they help us to assign besides the Beremend cemetery's younger horizon, also the Paks, and Szárazd burials to this phase, i.e. to the later decades of the first half of the $5^{\text {th }}$ century, or even to the beginning of the second half of this century. ${ }^{73}$

Now, the interesting consequence of this is that according to this chronological framework it is more than reasonable to assume that the aforementioned two graves and the younger horizon of the Beremend site are coeval with the earliest burials of the Szentlörinc cemetery. This makes perfect sense considering the fact that the east Alpine animal-headed fibulae and Certosa 13 type brooches (and also some further object types) appear both among the material coming from these graves ${ }^{74}$ and among the stray finds of the Beremend site. ${ }^{75}$ As a result, it cannot be ruled out that in chronological terms the Szentlörinc cemetery and the 'Beremend-type' burials overlap at least to some extent.

\section{A MISSING LINK}

At this point one might ask if this separation of the two groups is still valid. Is it possible to link these groups and create a framework of the funerary customs that incorporates all the Middle Iron Age burials from the southern part of Transdanubia?

To begin with, it has already been pointed out that Szentlörinc is not the sole Middle Iron Age cemetery in the southern part of Transdanubia. Both Beremend and Tolna-Mözs yielded either stray finds or further burials indicative of the existence of a formal cemetery. Unfortunately, however, until further investigations of these sites, they are not able to help us determining the relationship between the 'Beremend-type' burials and the ones represented by the Szentlörinc cemetery. However, in order to be able to create the framework a well-investigated and well-documented site is needed.

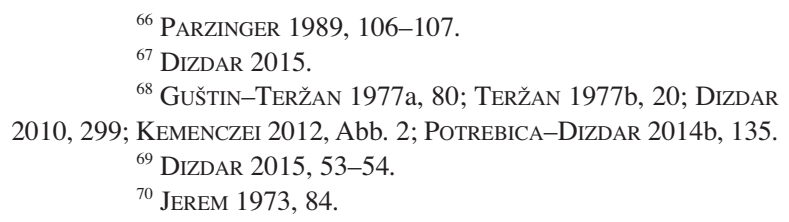

\footnotetext{
${ }^{71}$ SZABÓ 2012, 363-364.

${ }^{72}$ PARZINGER 1989, 107.

${ }^{73}$ PARZINGER 1989, 125

${ }^{74}$ PARZINGER 1989, 125.

75 JeREM 1973, Abb. 8.
} 


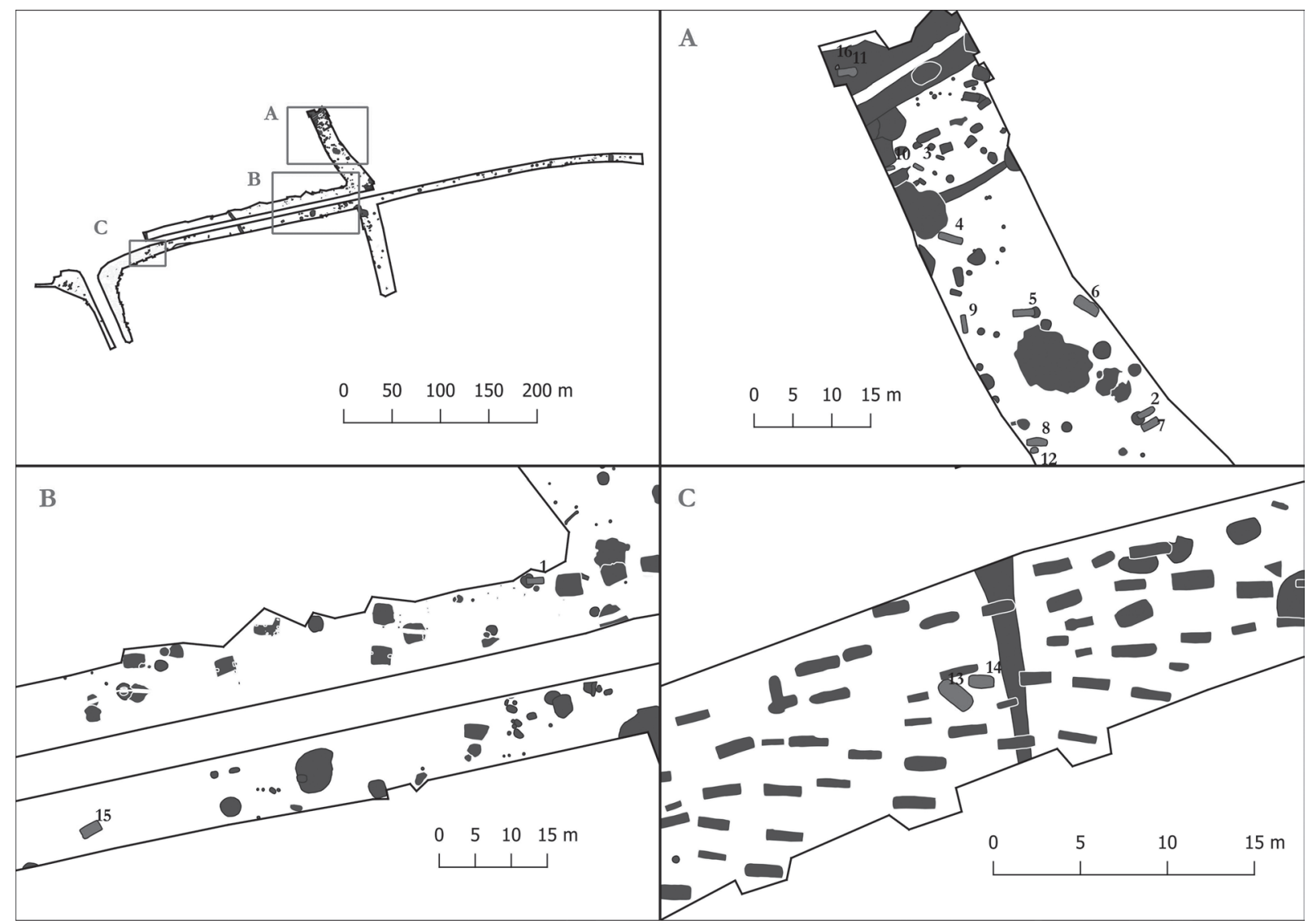

Fig. 11. The layout of the hitherto excavated graves of the Alsónyék cemetery

Due to the planned construction of the M6 highway, during 2008-2009 salvage excavations were conducted in the northeastern vicinity of Alsónyék, Tolna County. ${ }^{76}$ The investigations carried out by the archaeologists of the Mór Wosinsky Museum under the leadership of János Gábor Ódor revealed 16 graves that can undoubtedly assigned to the Middle Iron Age, so it is currently the second largest cemetery of the period under discussion in the region between the Sava and Kapos rivers, however, considering the shape of the excavated area and the results of the geophysical survey conducted by Kurt Rassmann and his colleagues ${ }^{77}$ it is reasonable to reckon with several further graves still unexcavated (Fig. 11).

\section{Natural setting and layout of the cemetery}

Before I would address the cemetery and the graves in detail, it is useful to describe the environs of this site, because it shows clear similarities with the natural settings of the aforementioned burial grounds. Based on the maps of the First Military Survey of the Habsburg Empire, the Middle Iron Age cemetery was located between the right banks of the Sárvíz creek prior to the river regulations in the $19^{\text {th }}$ century and the Szekszárd hills, respectively (Fig. 12). The landscape east of the site used to be characterised by vast marshlands formed by the Sárvíz creek and the Danube River. ${ }^{78}$ Obviously, due to their geographical proximity in this respect the Alsónyék site has much in common with the cemetery of Tolna-Mözs, but the similarities are quite remarkable with the Beremend and Szárazd

${ }^{76}$ The publication of the cemetery is going to be published soon (Soós, in press).

\footnotetext{
${ }^{77}$ RASSMANN et al. 2015, Fig. 10.

${ }^{78}$ Károlyi 1973, Fig. II.41; Balázs Kovács 2015, 217.

Acta Archaeologica Academiae Scientiarum Hungaricae 71, 2020
} 


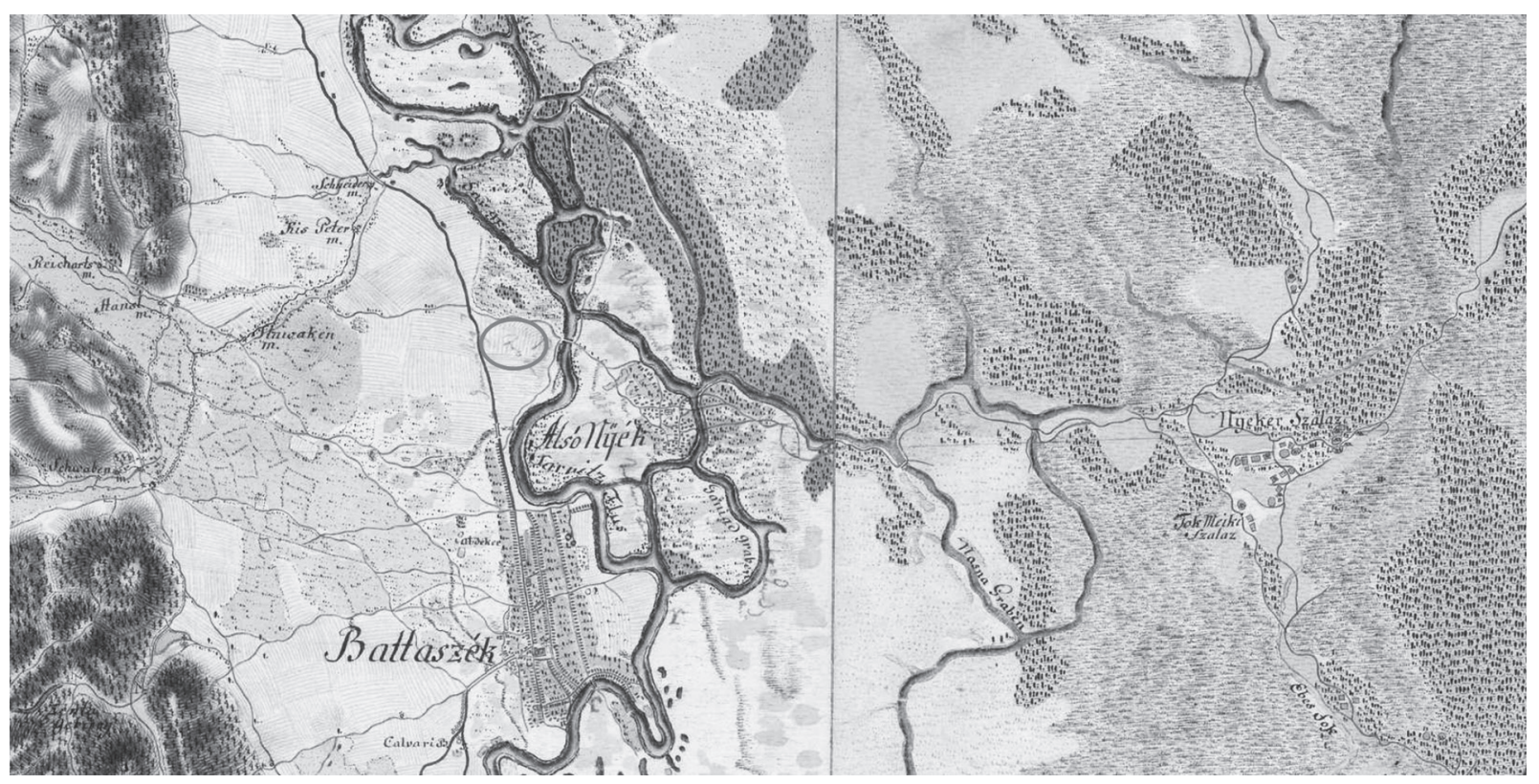

Fig. 12. The environs of the cemetery near Alsónyék on the First Military Survey of the Habsburg Empire

(Source: https://mapire.eu/hu/map/firstsurvey-hungary/ (Access: 2019.12.29)

sites, too. Moreover, already E. Jerem brought attention to the fact that the cemetery of Szentlörinc is situated relatively close to a creek called Ökörvíz. ${ }^{79}$

One of the most unsettling feature of the Beremend site is that in spite of having investigated a relatively large area around the two graves the archaeologists of the Janus Pannonius Museum did not succeed in finding further burials of the cemetery whose existence was proved by the large amount of stray finds collected in later years. I would like to argue that behind this 'mystery' there might be in fact a characteristic feature of the layout of the Middle Iron Age cemeteries in the southern part of Transdanubia and even in the regions further to the south and southeast.

As already discussed, the 'Beremend-type' graves tend to be discovered in an entirely separated positon, ${ }^{80}$ with seemingly no other burials nearby. Such graves can be observed in the southwestern part of the excavation area of the Alsónyék site. Grave 15 is probably the best example considering that it was separated from its nearest known neighbours by a distance of 70 and $140 \mathrm{~m}$, respectively. ${ }^{81}$ As a result, it is very reasonable to believe that a very similar layout of the graves might be reckoned with in the case of the Beremend site, on the other hand, it also gives hope that there might be even more burials at either aforementioned site associated with the 'Beremend-type' graves. There is another example supporting this assumption. Near Szeged-Kiskundorozsma, in southeast Hungary a Middle Iron Age cemetery of some 31 graves had been unearthed. From several aspects this site is closely linked to the Szentlörinc and Vinkovci sites, ${ }^{82}$ but above all to the recently discovered cemetery near Novi Sad, ${ }^{83}$ hence closely linked to the south Pannonian late Hallstatt group. The graves of the Szeged site form two distinct groups, but there is one grave which was at a $130 \mathrm{~m}$ distance from the rest of the cemetery, unfortunately, however, its exact chronological position is somewhat problematic (Fig. 13). Although the archaeologists who excavated the Szentlorrinc cemetery claim that the full extent of the graveyard has been explored, it is still worth raising the question whether there might be further burials located at relatively large distances away from the graves hitherto unearthed.

Another peculiarity of the Beremend graves was that they were placed closely next to each other so that their longitudinal axes were parallel, at least according to the finders' account. ${ }^{84}$ Set aside the relatively densely

79 JEREM 1968, 159.

${ }^{80}$ METZNER-NEBELSICK 2002, 204.

${ }^{81}$ This might be a coincidence, nevertheless, but it is worth mentioning that the geomagnetic survey conducted by K. Rassmann and his colleagues revealed that the area lying to the south of the grave has relatively few loosely scattered archaeological features. RASSMANN et al. 2015, Fig. 10.

${ }^{82}$ PiLling-Ujvári 2012, 234

${ }^{83}$ АНЂЕЛИЋ 2017.

${ }^{84}$ JEREM 1973, Abb. 2. 


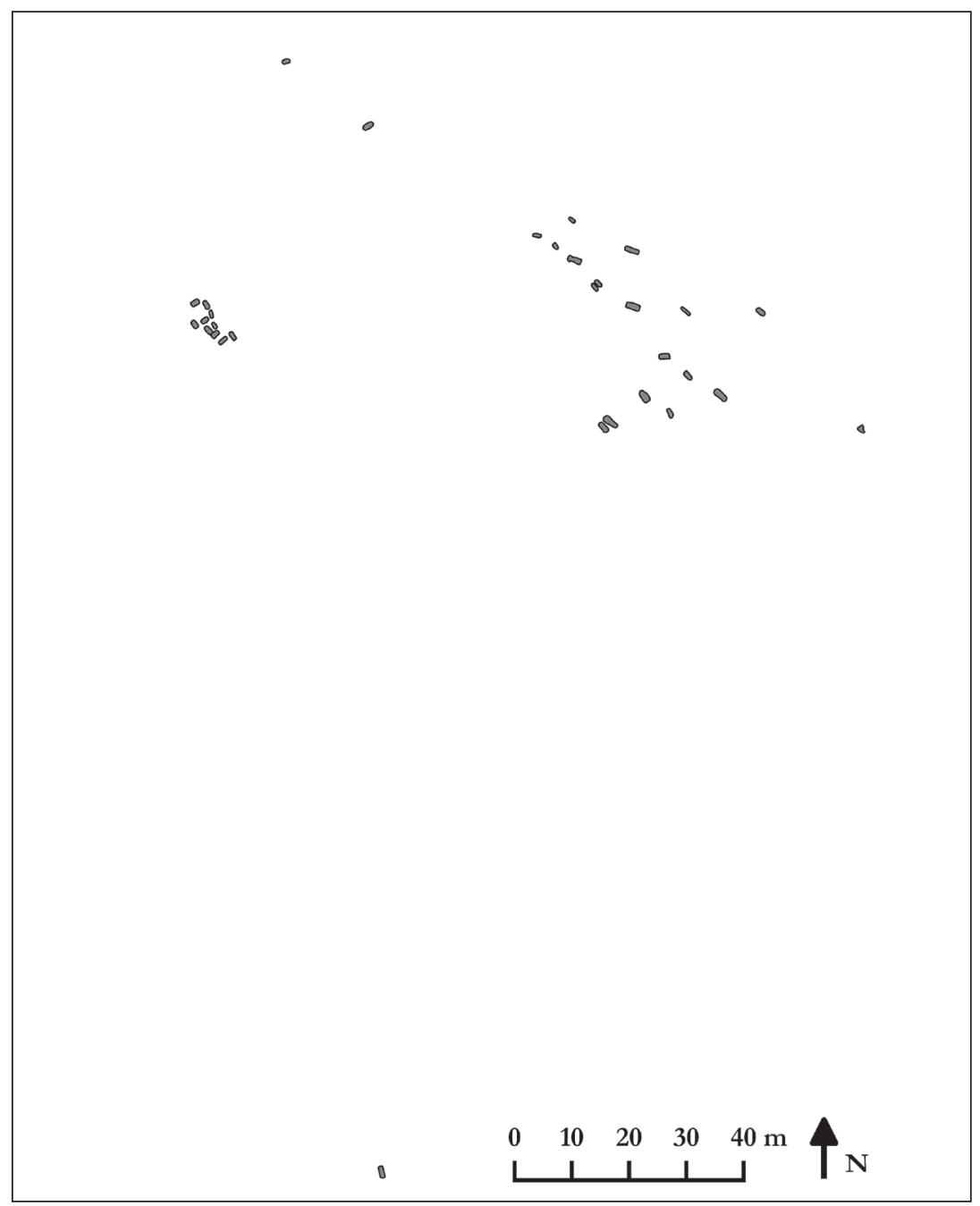

Fig. 13. Layout of the Szeged-Kiskundorozsma cemetery

placed graves of the Szenlorinc cemetery, such examples were missing in the region under discussion. However, there are noticable candidates for comparable situations further to the south. The Vučedol burial's description by J. Brunšmid led archaeologists to believe for a century that the items found somewhere between Vukovar and Sotin had originated from one burial, however, as M. Dizdar and A. Tonc have recently pointed out based on the composition of the grave goods reckoning with two distinct burials seems more reasonable. ${ }^{85}$ Nevertheless, one cannot rule out the possibility that contrary to the situation at the Beremend site, these were in one grave pit, similar to the examples of double burials from Szentlörinc, Vinkovic-NaMa. The same applies for the Adaševci burial presented by M. Hoernes in $1901 .{ }^{86}$ Of course, this is highly hypothetical, but the Alsónyék cemetery offers an example that makes the above scenario fairly probable. Again, Grave 13 and 14 were situated quite far from what is now believed to be the densest part of the cemetery, and were placed very close to each other (Fig. 11). Interestingly though, contrary to the Beremend graves they were neither particularly rich in terms of grave goods, nor placed exactly parallel to each other. The latter is worth discussing, because this does not necessarily prove that graves' relative positon had not been correctly reconstructed at the Beremend site. There are, in fact, numerous examples where graves placed next to each other have parallel longitudinal axes. In the case of the Alsónyék cemetery such examples 
are Graves 2 and 7 on the one hand, and Graves 8 and 12 on the other. Moreover, the best known analogy of the Grave 1 in the Beremend cemetery, the burial discovered near Tolna-Mözs has also been found side by side with a grave which, unfortunately, had been heavily damaged. ${ }^{87}$

\section{The character of the graves}

It is quite remarkable that the Alsónyék cemetery also yielded graves in which the deceased were adorned with astragal belts, Certosa 5 fibulae and glass paste beads, the most characteristic finds of the 'Beremend-type' graves. Examples are Grave 2 and 6. In fact, this is the first time we have the opportunity to see graves with such characteristic grave goods within a well-explored context, and the overall picture gives the impression that observed dissimilarity between the 'Beremend-type' graves and the cemeteries like Szentlörinc or Vinkovci-NaMa in terms of the 'average richness of the burials' could indeed be the result of the different social standing of the deceased, and might not only be a chronological issue. In fact, this is in accordance with the notion that the former might be seen as the burials of a privileged group within the Middle Iron Age society. ${ }^{88}$ However, one has to be cautious regarding the conclusions, because several of the burials at Alsónyék were partially or entirely robbed, but this is another similarity with the Szentlörinc cemetery. ${ }^{89}$

It is hardly surprising that Grave 2 and 6 contained inhumation burials. As earlier discussed, based on current knowledge this is the dominant type of burial rite, among the graves found at the Alsónyék site there are only 3 exceptions so far. Besides inhumation burials the Szentlörinc site yielded several cremations and there were 4 graves without human remains. The latter were categorized by E. Jerem as 'symbolic' burials. ${ }^{90}$ In the case of Alsónyék there is only one more or less apt candidate to be assigned to this category. As far as its dimensions and shape are concerned, Grave 7 is not an exception, but due to the missing human remains it might be regarded as a cenotaph (Fig. 14). ${ }^{91}$ Interestingly though, contrary to the examples from Szentlörinc in which decent amounts of grave goods was found, ${ }^{92}$ in this case only one segment of an astragal belt came to light, which might be the result of either disturbance or grave robbery, nevertheless.

Of course this example is hardly a persuasive evidence that would suggest that the cemetery of Alsónyék has that varied burial customs as the Szentlörinc site. In order to be able to show this, we have to turn to Grave 14 and Grave 16. The latter was found at the very fringes of the excavated area's northern section. Unfortunately, it came to light heavily damaged, but what seems to be clear is that this was in fact a cremation in an urn. Due to the disturbance of the grave some grave goods might possibly be missing, but an iron knife and a whetstone were definitely part of this assemblage (Fig. 15). Interestingly, no urn graves were found in the Szentlörinc cemetery and up to this point no well-documented cremation burial has appeared at the sites associated with the Srem group. ${ }^{93}$ The question is whether this example from Alsónyék is an isolated one. It is worth mentioning, that on the other side of the Danube River, urn graves are frequently occurring, although, their proportion among the burials in different cemeteries varies greatly. ${ }^{94}$ This bears significance because similarly to the Alsónyék cemetery the site providing the other example is also situated in close proximity to the Danube River. Grave 55 of the Mözs cemetery yielded a somewhat damaged urn that contained creamed human remains, molten glass paste beads, and molten pieces of presumably a Certosa fibula (Fig. 16). Arguably, the overall picture of this grave resembles well the urn graves of the Vekerzug culture especially the ones in its southern cemeteries insofar as it contains jewellery that had possibly been placed onto the pyre with the deceased.${ }^{95}$ For the time being, however, the question shall remain open whether there are actual cultural links behind this similarity in this burial custom between the regions on either side

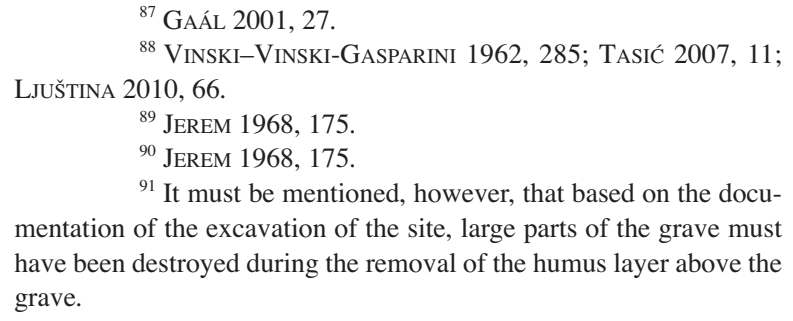

${ }^{91}$ It must be mentioned, however, that based on the documentation of the excavation of the site, large parts of the grave must have been destroyed during the removal of the humus layer above the grave.

\footnotetext{
${ }^{92}$ Grave 11: JeRem 1968, 162, Grave 19: ibid. 163, Grave 54: ibid. 171

${ }_{93}$ Only the heavily disturbed cemetery in Šabac was supposedly biritual, at least according to M. Vasilijević (VASILIJEVIĆ 1976), R. Vasić (VASIĆ 1977, 29; VAsić 1987, 556), D. Popović (Popović 1981, 31).

${ }^{94}$ KemencZei 2009, 29; Kozubová 2013, Obr. 97.

${ }^{95}$ Algyő: BENDE 2003, 67; Sándorfalva-Eperjes: GALÁNTHA 1985, 118; Szabadszállás-Józan: HoRvÁtH 2001，97; SzentesVekerzug: PÁRDUCZ 1955, 102.
} 


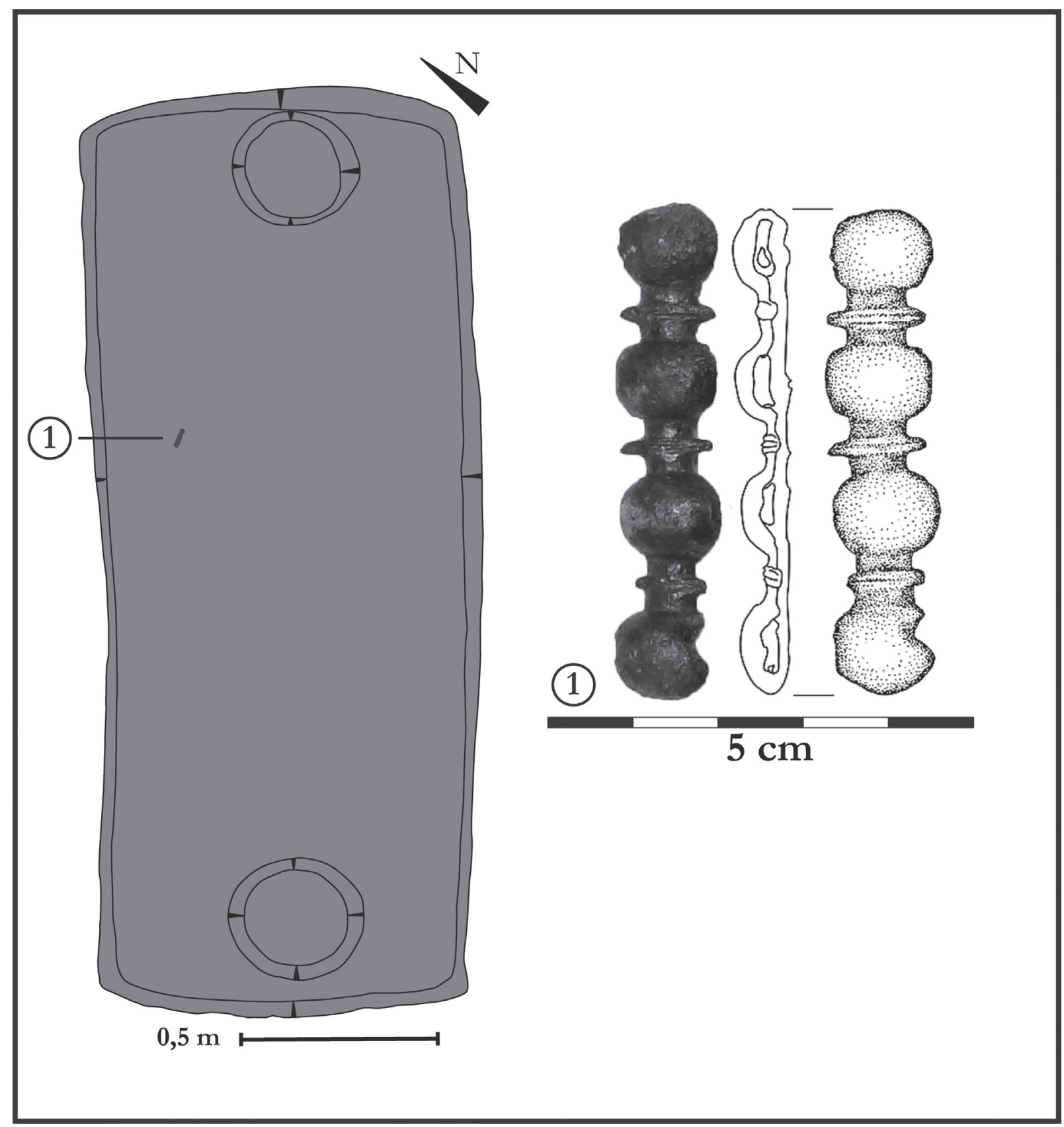

Fig. 14. Grave 7 of the Alsónyék cemetery

of the Danube River. It is notable, nonetheless, that the items associated with Grave 16 bear no obvious marks of exposure to strong heat.

Whereas urn graves are missing from the Szentlörinc cemetery, burials with strayed cremated remains occurred, but despite the same burial rite none of these is quite as similar to Grave 14 of the Alsónyék graveyard as Grave 11. Both graves had a W-E orientation but what seems to be more important is the relative positions of the grave goods consisting of an iron spear and knife in both cases. ${ }^{96}$ As E. Jerem has already pointed out, the arrange-

${ }^{96}$ JEREM 1968, 162. 

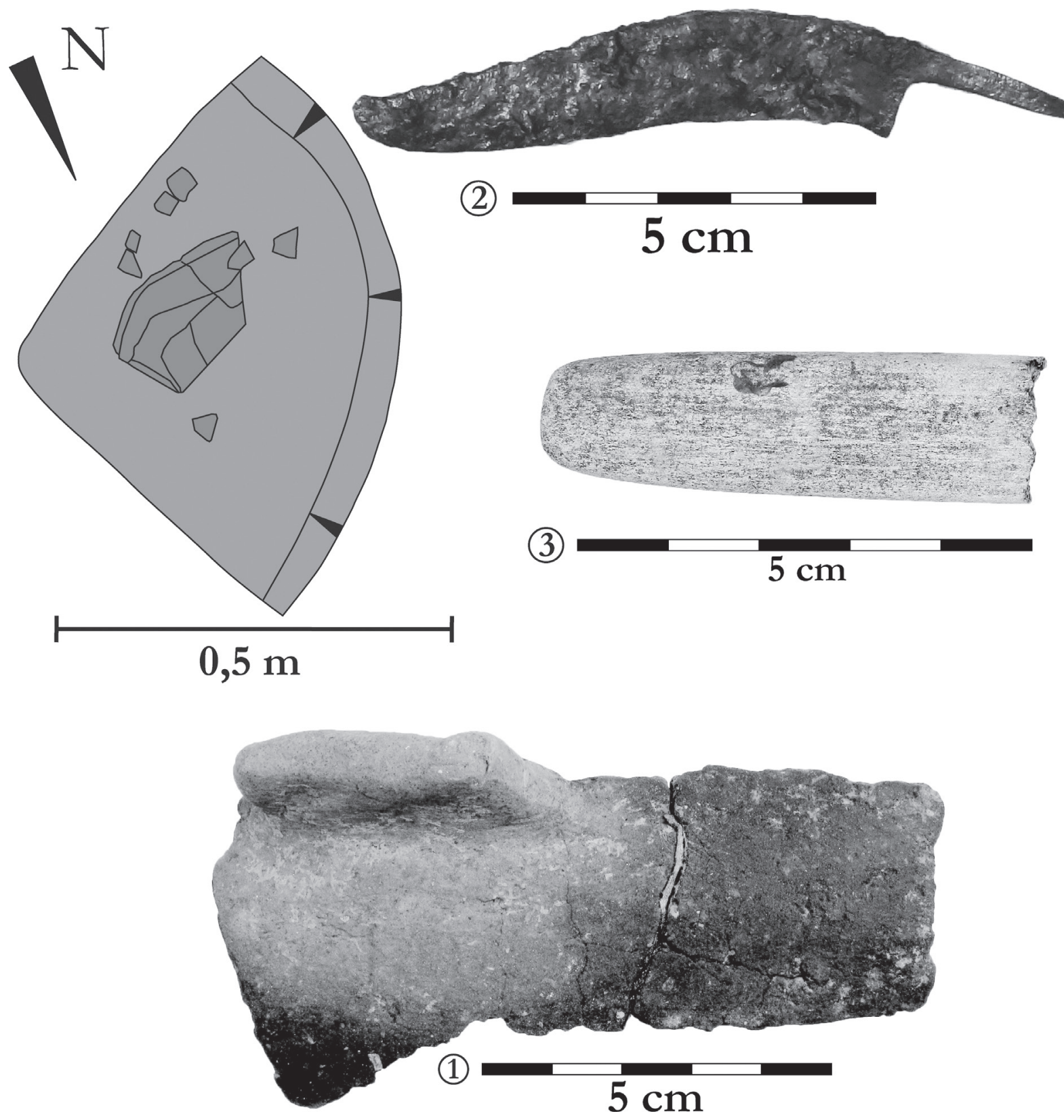

Fig. 15. Grave 16 of the Alsónyék cemetery

ment of items inside the grave pit resembles remarkably that seen in the inhumation graves, now this seems to apply for the Grave 14 (Fig. 17).

Interestingly, there was no ceramic object directly associated with the burials of the 'Beremend-type' in Transdanubia. In contrast, potteries were relatively often included among the grave goods in the case of the Szentlörinc cemetery. Obviously, given the aforementioned urn grave the Alsónyék cemetery indeed yielded ceramic vessels. But what is more important, among the graves whose grave furnishing included astragal belt, glass paste beads and Certosa fibulae there were also potteries (Fig. 18), whose analogies are known from both the 

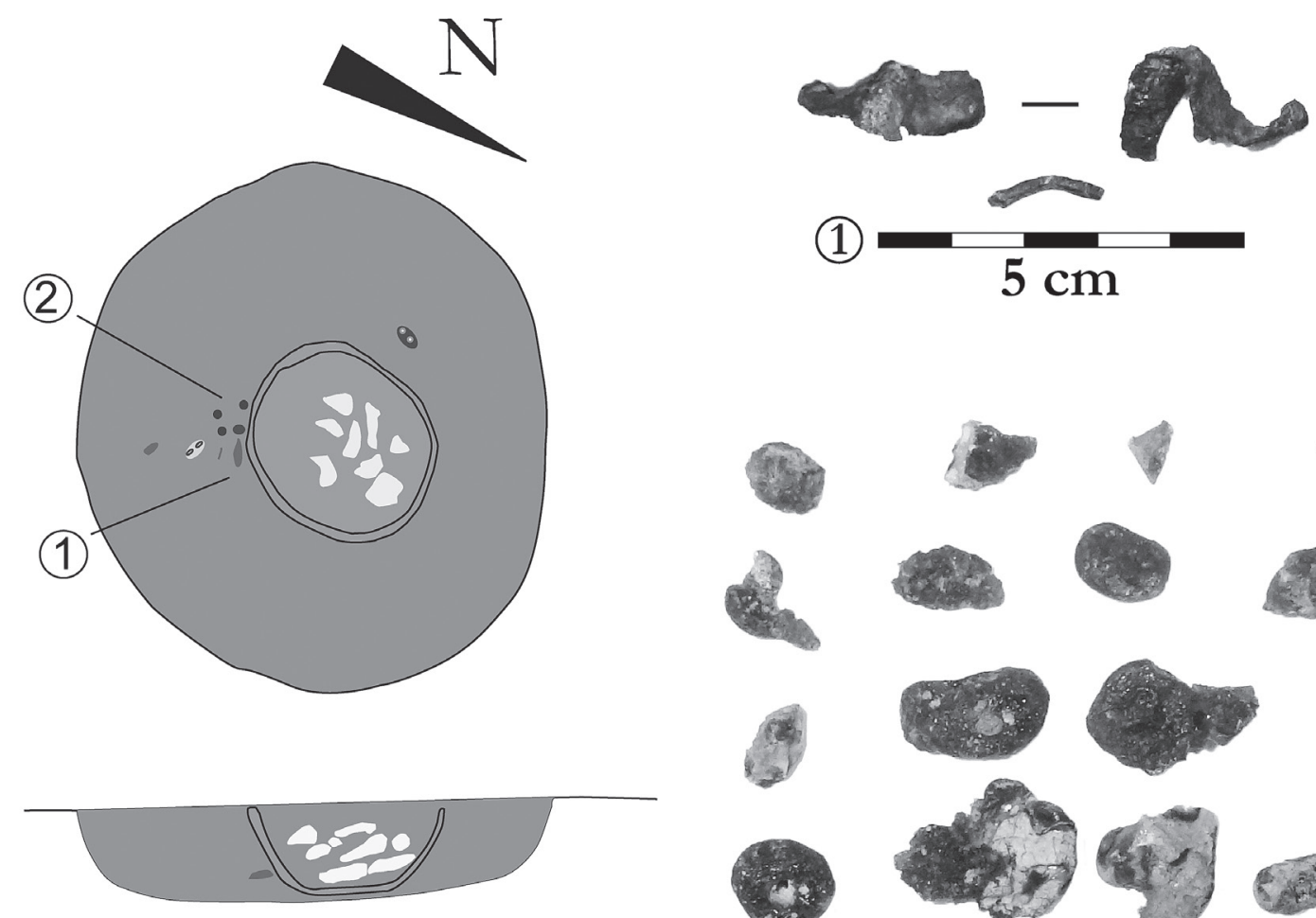

(1)
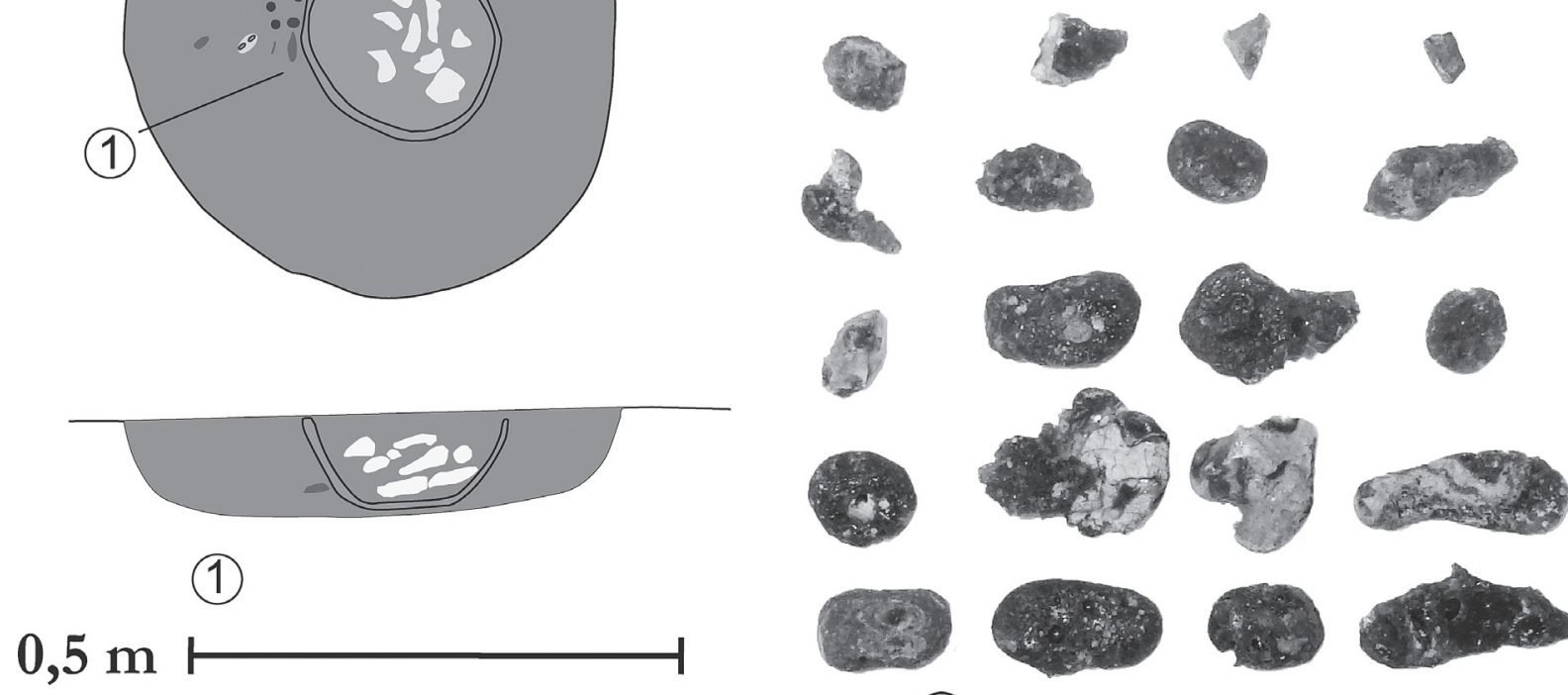

(2)

Fig. 16. Grave 55 of the Tolna-Mözs cemetery

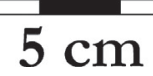

Szentlörinc cemetery ${ }^{97}$ as well as the Szajk settlement. ${ }^{98}$ In fact, these so-called kantharoi are often seen as one of the most characteristic pottery forms of the Middle Iron Age population of South Pannonia. ${ }^{99}$

\section{Chronological outline of the cemetery}

In my view, one of the key elements behind the exceptional significance of the Beremend graves is that they showed that characteristic types of the Certosa horizon in Slovenia did in fact appeared in the southern part of Transdanubia very early on. Of course, this site is situated along one of the most important communication routes connecting the southern part of Transdanubia to the area of the Dolenjska group in today's Slovenia. ${ }^{100}$ Now, the reasonable question to ask is when this material appeared in regions further to the north, namely in the region of Alsónyék, Tolna and Szárazd.

Unfortunately, items that would allow such precise dating as in the case of Grave 2 in Beremend are currently absent from the Late Hallstatt material of today's Tolna County. Let us not forget, however, that recently some authors suggested that the communication between the region of the Lake Balaton and that of the Dolenjska group never ceased entirely during the Ha D1-D2 periods. ${ }^{101}$ But evidence for this from the region currently discussed is

${ }^{97}$ JEREM 1968, Fig. 23,28/7, Fig. 25,40/8, Fig. 26,46/3, Fig. 29,63/2, Fig. 29,67/10-11.

${ }^{98}$ GÁTI 2014, 117. 2010, 299.

99 JEREM 1996, 103; MAJNARIĆ-PANDŽIĆ 2009, 238; DIZDAR

${ }^{100}$ KovaČEvić 2007, 107; KovaČEviĆ 2008, 67.

${ }^{101}$ HORVÁtH 2015; JáKY 2017, 388.

Acta Archaeologica Academiae Scientiarum Hungaricae 71, 2020 


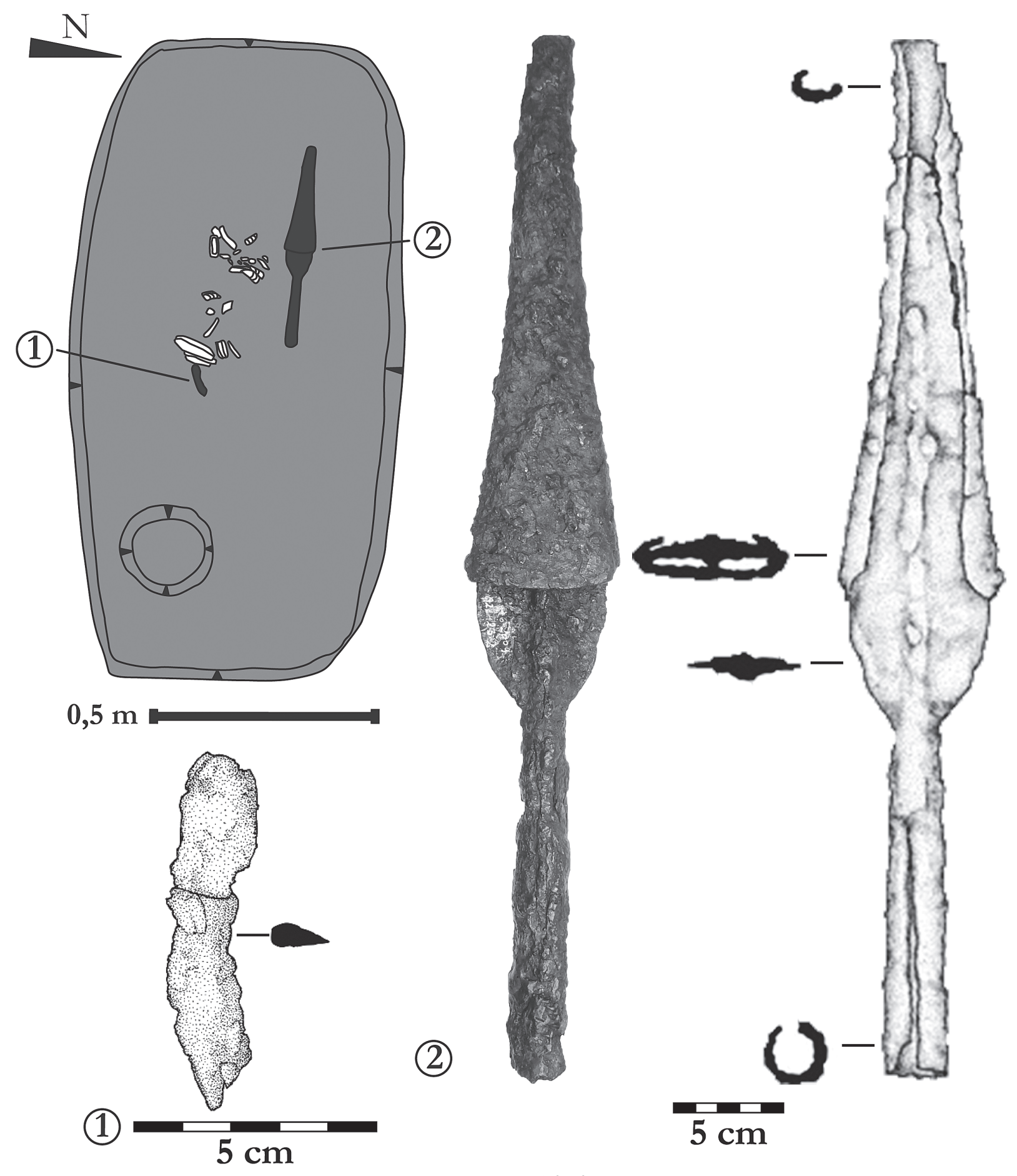

Fig. 17. Grave 14 of the Alsónyék cemetery 

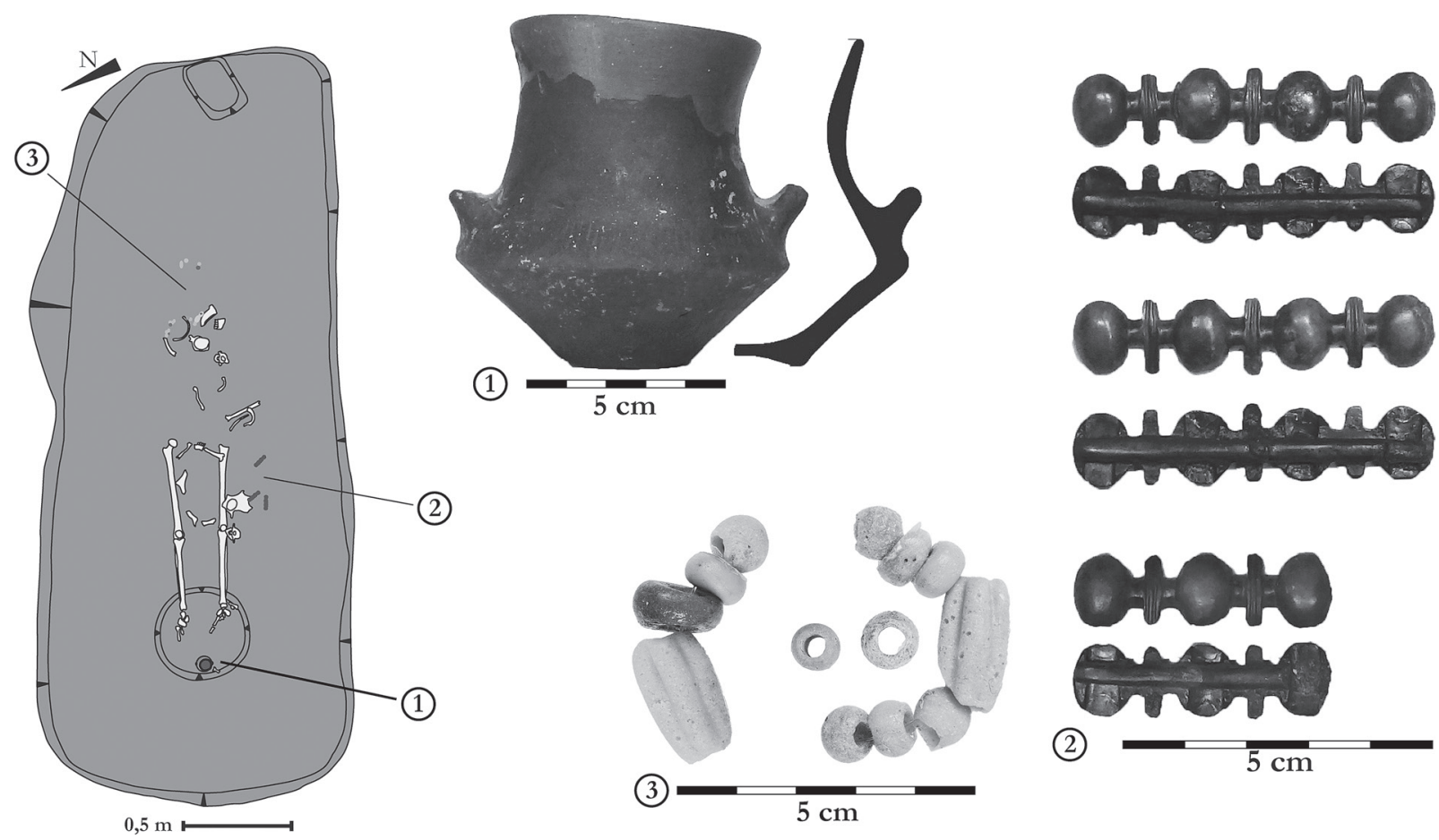

Fig. 18. Grave 6 of the Alsónyék cemetery

still scarce, though. Frankly, there is only one item that might suggest that the material of the early phase of the Certosa horizon appeared here is the fibula of type Certosa 2a found near Gyulaj as a stray find. ${ }^{102}$

What seems to be certain is that the cemeteries near Alsónyék and Tolna-Mözs were probably in use during the first half of the $5^{\text {th }}$ century. That is the strongest conclusion that the Certosa 5 type fibulae present in the material from both sites currently allow. This means, however, that it is fairly reasonable to assume that both cemeteries have graves preceding the first phase of the Szentlörinc cemetery in chronological terms. In addition, there are at least two graves in the Alsónyék cemetery suggesting that this graveyard might have also been synchronous with the Szentlörinc site during the latter's first and possibly second horizons. Both B. Teržan and H. Parzinger brought attention to the iron fibulae in the Szentlörinc cemetery and claimed that these items are characteristic finds of the latest phase of the Hallstatt Age, i.e. the second and third horizons in the case of the inner chronology of the cemetery and the $10^{\text {th }}$ horizon in Parzinger's framework. ${ }^{103}$ Moreover, according to B. Teržan, it is very likely that these might have appeared in the southern Pannonian region almost parallel with their emergence in the area of the Dolenjska group, ${ }^{104}$ i.e. at the beginning of the Negova horizon. ${ }^{105}$ This bears significance because there is at least four such fibulae among the burial furniture of Grave 1 of the Alsónyék cemetery. But this is not the only fact supporting the idea that this grave might belong to the second half of the $5^{\text {th }}$ century BC. Considering its grave goods as an assemblage this grave seems to be closely related to a number of graves from Szentlörinc, especially Grave 29 and 33 which feasibly belong to the second phase of the cemetery. ${ }^{106}$

Now, it is worth taking a slight detour, and entertaining the idea that one of the burials of the Alsónyék cemetery might predate the $5^{\text {th }}$ century BC. Grave 16 has already been addressed very briefly. Unfortunately, shards of the urn are now lost and thus typological analysis of the vessel is not possible. There are two further items associated with this burial severly disturbed during the removal of the humus layer. Unfortunately, neither of them allows a precise dating, however, the more or less characteristic curvated shape of the iron knife raises the question whether the grave might predate the latest stage of the Hallstatt Age. In M. Gavranović's perception knifes of HVALA 2012, 256

${ }^{102}$ MÁRton 1933, Taf. 6.1; TeržAn 1977a, 320; TeCCO

${ }^{103}$ TERŽAn 1977a; PARZINGER 1989, 107.

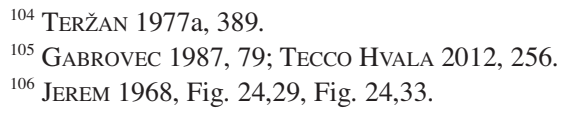

Acta Archaeologica Academiae Scientiarum Hungaricae 71, 2020 
similar shape resemble the knives of the Urnfield period and might be dated to the early Hallstatt periods. Indeed, similar knives came to light from the Statzendorf cemetery, namely from graves dated to the Ha C1-C2 periods. ${ }^{107}$ Furthermore, the specimens found in the Sulmtal cemetery date to the first phase of the site. ${ }^{108}$ Despite these examples, however, dating this grave to a time preceding the $5^{\text {th }}$ century is simply not reasonable without further evidence.

Fibulae play the most essential role in defining the chronological positions of the Middle Iron Age burials in the region under consideration, however, the case of Grave 15 of the Alsónyék cemetery presents an exception (Fig. 19). Even though, the grave assemblage besides an iron spearhead, whetstone, and iron awl included a Certosa 5 type brooch, there is a further item of chronological significance in this grave, and it is a belt plate with central bar. In 1977, B. Teržan published an assessment of the warrior graves of the $5^{\text {th }}$ century BC, in this she made the observation that these belts spread in the Dolenjska group in the Negova horizon and soon after appeared also in the western Balkans and in southern Pannonia. ${ }^{109}$ In the case of the specimens originating from the Szentlörinc cemetery a dating to the period of the Certosa horizon seems unlikely given the ring-shaped belt buckle among the grave goods found in Grave $31 .{ }^{110}$ Also, E. Jerem assigned the graves with such belt to the second phase of the cemetery. ${ }^{111}$ However, whereas there is no reason for changing the dating of these belts in Szentlörinc, in the case of the specimens from the area of the Dolenjska group, S. Tecco Hvala proposed that these elements of male attire already appeared during the later stage of the Certosa horizon. ${ }^{112}$ Unfortunately, the closest analogies of the belt clasp of Grave 15 are either stray finds ${ }^{113}$ or from uncertainly dateable contexts, ${ }^{114}$ thus, they cannot really provide more insight into the exact chronological position of this specimen. Now, it is worth returning to the fact that Grave 15 yielded also a Certosa 5 type brooch, whose analogies are completely absent among the finds of the Szentlörinc cemetery. Thus, it seems feasible that this grave belongs to either the period preceding the use of the Szentlörinc cemetery, or to the very first horizon of the graveyard. ${ }^{115}$ Consequently, Grave 15 might be dated parallel with the Szárazd and Paks burials to the later decades of the first half or to the beginning of the second half of the $5^{\text {th }}$ century $\mathrm{BC}$, according to the framework proposed by H. Parzinger. ${ }^{116}$

In order to gain more insight into the absolute chronology of the cemetery AMS radiocarbon analysis was conducted on one sample taken from the lower right second molar tooth of the deceased buried in Grave 15. Initially, the analysis of two samples from different graves was planned, but due mainly to the bad preservation of the human remains, only one sample turned out to be capable of providing the needed organic material. The analysis was carried out in the HEKAL Laboratory of the Institute of Nuclear Research of the Hungarian Academy of Sciences (ATOMKI) in Debrecen. The results of this analysis are summarised in the table below. The radiocarbon date was calibrated with the OxCal v4.3.2 software (Bronk Ramsey 2017), with the IntCal 13 atmospheric curve (Reimer et al. 2013).

The effects of the so-called 'Hallstatt-plateau' of the calibration curve are quite apparent, and hence the calibrated age interval is relatively broad. Nevertheless, there is additional useful information worth considering which might allow a somewhat more precise dating. On the one hand, Slovenian scholars of the Bronze and Iron Ages succeeded in compiling a large sequence of radiocarbon dates from contexts in today's Slovenia. ${ }^{117}$ The model they generated resulted in an immensely valuable absolute chronological framework which to some extent might be of help in refining the age interval of Grave 15. Due to the firm assumption that Certosa 5 type fibulae could not have appeared in the southern areas of Transdanubia earlier than in today's Slovenia, the lower boundary of the modelled radiocarbon dates obtained for burials of the Certosa horizon can be used as a refining factor in the recalculation of the calibrated age interval of Grave 15 (Fig. 20). Of course, the typochronological considerations briefly addressed already allow to draw the conclusion that Grave 15 of the Alsónyék cemetery can hardly be older than the Beremend burials, i.e. it is exceedingly unlikely that this burial would predate the $5^{\text {th }}$ century BC.

\footnotetext{
${ }^{107}$ REBAY 2006, 289-290.

${ }^{108}$ Dobiat 1980, 144.

109 TERŽAN 1977b, 14-16.

${ }^{110}$ JEREM 1968, Fig. 24,31/2.

111 JEREM 1968, 177.

112 Tecco Hvala 2012, 184.

${ }^{113}$ KOROŠEC 1943, 59.

${ }^{114}$ RADIMSKY 1895, 207.
}

${ }^{115}$ However, it is worth highlighting that in the southern Pannonian region there are examples suggesting that this type of brooches remained to be worn for a relatively long period of time. For instance: the Grave 21 at Greda M. Petrović ml. in near Donja dolina (TrUHELKA 1904, Taf. 44,27-37) contained a fibula of this type as well as a Certosa 10 type brooch a characteristic element of attire during the Negova-horizon. Consequently, Z. Marić dated this burial to the IIc phase in his chronological framework (MARIĆ 1964, 43).

${ }^{116}$ PARZINGER 1989, 125.

117 TERŽAN-Č́REŠNAR 2014. 

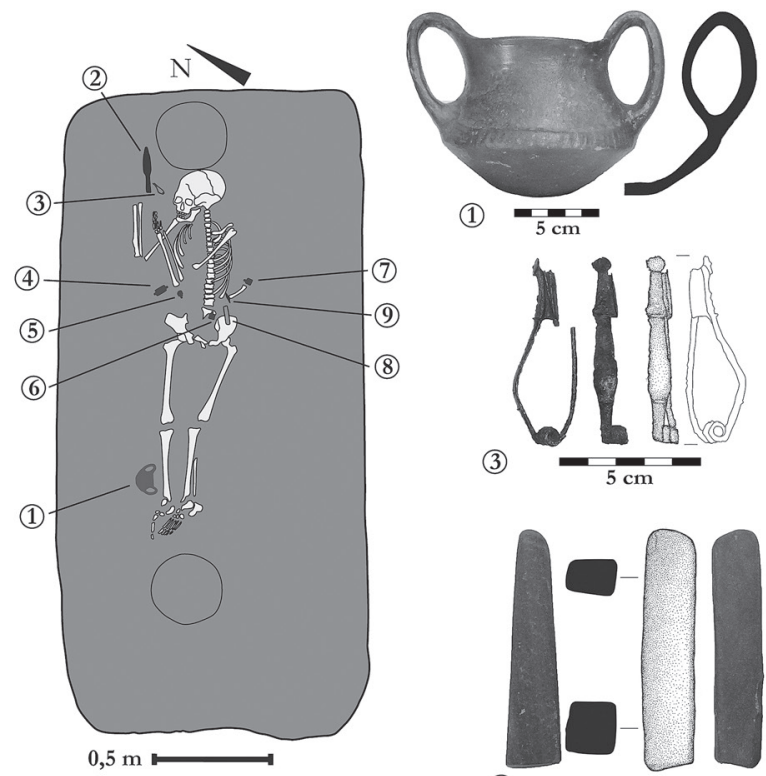

(1) $\frac{}{5 \mathrm{~cm}}$
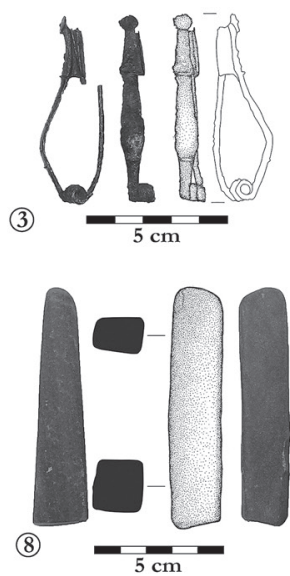

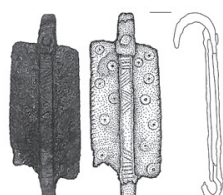

(5)

(6)
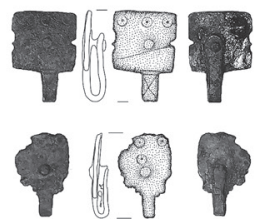

(7)
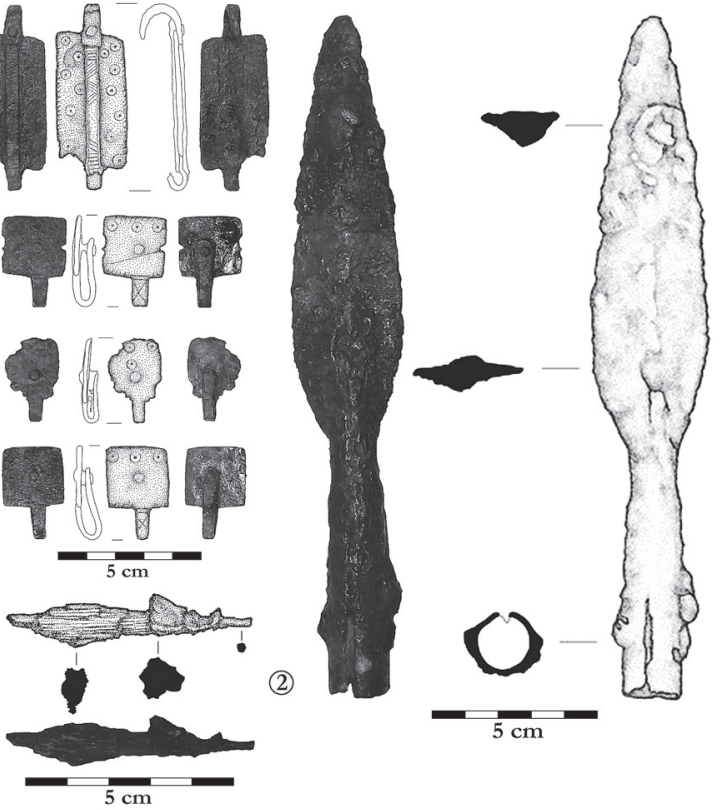

Fig. 19. Grave 15 of the Alsónyék cemetery

Table 1.

AMS radiocarbon date from Grave 15 of the Alsónyék cemetery

\begin{tabular}{|c|l|l|l|l|}
\hline \multicolumn{1}{|c|}{ Lab. No. } & \multicolumn{1}{|c|}{ Feature } & \multicolumn{1}{|c|}{ Dated material } & \multicolumn{1}{|c|}{ 14C Age $(\mathbf{B P})(\mathbf{\pm 1 \sigma})$} & \multicolumn{1}{c|}{$\begin{array}{c}\text { Calibrated calendar years } \\
(\mathbf{c a l} \mathbf{B C})( \pm \mathbf{2 \sigma})\end{array}$} \\
\hline DeA-19355 & $\begin{array}{l}\text { Grave 15 } \\
(\text { Obj. no. } 465)\end{array}$ & human tooth & $2446 \pm 27$ & $751-410 \mathrm{BC}$ \\
\hline
\end{tabular}

It is worth touching upon the lower limit of the age interval of the burial. Based on this, one can be fairly confident to believe that the grave predates the $4^{\text {th }}$ century. This is quite important to note given the fact that belt hooks similar to the one recovered from the grave under discussion came to light from contexts dated after $400 \mathrm{BC}$. One significant example is Grave IV/3 of the Novo mesto-Kandija cemetery. Based on the results of the radiocarbon analysis conducted on the sample collected from this grave it can be dated to the first half of the $4^{\text {th }}$ century BC (Fig. 21), ${ }^{118}$ and hence, the conclusion can be drawn that Grave 15 of the Alsónyék cemetery is certainly an older burial. This, however, does not imply that the Alsónyék cemetery was not still in use during the early decades of the $4^{\text {th }}$ century.

\section{THE BIGGER PICTURE}

I have been mainly focusing on the characteristics of the Late Hallstatt Age funerary record in southern Transdanubia and limited attention was paid to its larger cultural and historical context. Let us first address the latter. There is a wide agreement among researchers of the period that in the first half of the $6^{\text {th }}$ century BC the Eastern Hallstatt zone experienced a fundamental transformation. The tumuli excavated near Jalžabet and Regöly provide clear evidence that a new set of eastern elements had gradually begun to play an essential role in the representation of the highest strata of the Hallstatt society in the southern part of Pannonia at the end of the $7^{\text {th }}$ and in the first half of the following century. ${ }^{119}$ In addition, as a sign of strengthening ties to the Vekerzug culture the cultural elements

\footnotetext{
118 TERŽAN-ČREŠNAR 2014, 721.
}

119 ŠImeK 1998; ŠImeK 2001; SzabÓ-FeKete 2015; KovAČEVIĆ 2019. 


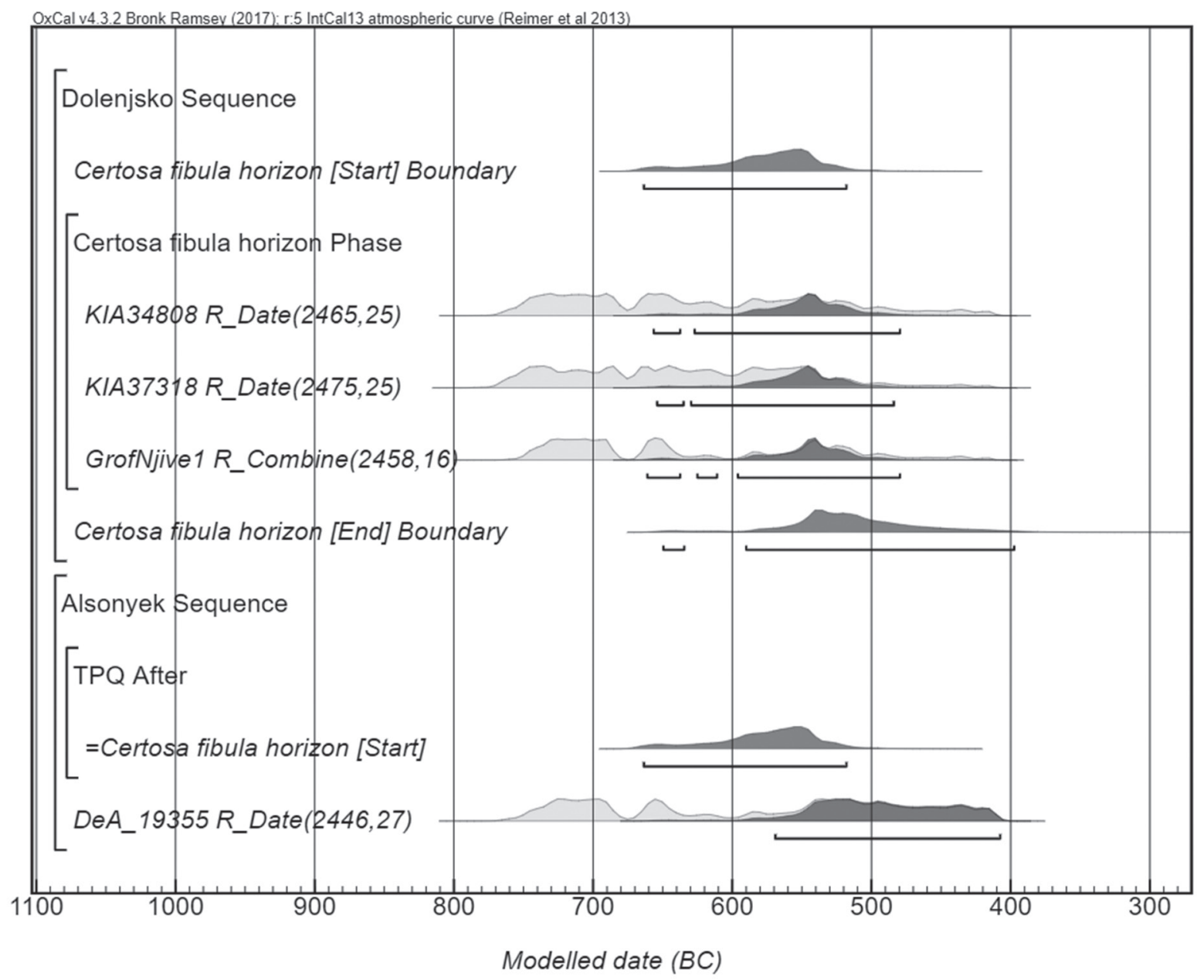

Fig. 20. Modelled age intervals for graves of the Certosa horizon and Grave 15 of the Alsónyék cemetery

of eastern origin appeared also in greater amount in settlement contexts and also in cemeteries in Transdanubia. ${ }^{120}$ Parallel to this, the previously strong contacts to the western and southwestern regions of the eastern Hallstatt zone seem to have weakened, ${ }^{121}$ but as recently published finds suggest never ceased to exist during this period of transformation. ${ }^{122}$ Arguably, the most significant changes occurred in the dominant burial customs and the settlement network, i.e. tumulus burials disappeared and several prominent hillforts were abandoned. ${ }^{123}$ Although, it is very tempting to see these radical changes as evidence for destructive military campaigns led by militant groups of eastern origin, other scenarios involving internal social tensions resulting in the phenomena listed above cannot be ruled out either. $^{124}$

As for the southern part of Transdanubia, this transition is very hard to trace at the moment given the fact that well-documented sites pertaining to the times between the beginning and the very end of the $6^{\text {th }}$ century BC are currently missing. Also, the largest tumulus cemeteries of the region, i.e. Nagyberki-Szalacska and Pécs-Jakabhegy need further investigations so that their chronological dimensions might be defined in more detail, because at this

\footnotetext{
JÁKY 2017.

${ }^{120}$ GÁl-Molnár 2004; KemenCZei 2010; HoRVÁtH 2015;

${ }^{121}$ Dular-Tecco Hvala 2007, 232.

${ }^{122}$ NAGY et al. 2012; HoRVÁth 2015; JÁKY 2017.
}

${ }^{123}$ TERŽAN 1998, It is worth mentioning though, that in the case of the hillfort on the Tihany peninsula the survival of the settlement during the Ha D3-Lt A periods is feasibly in light of the results of the excavtion led by J. Regenye (MARTON-REGENYE 2005, 52).

${ }^{124}$ EgG 2013. 


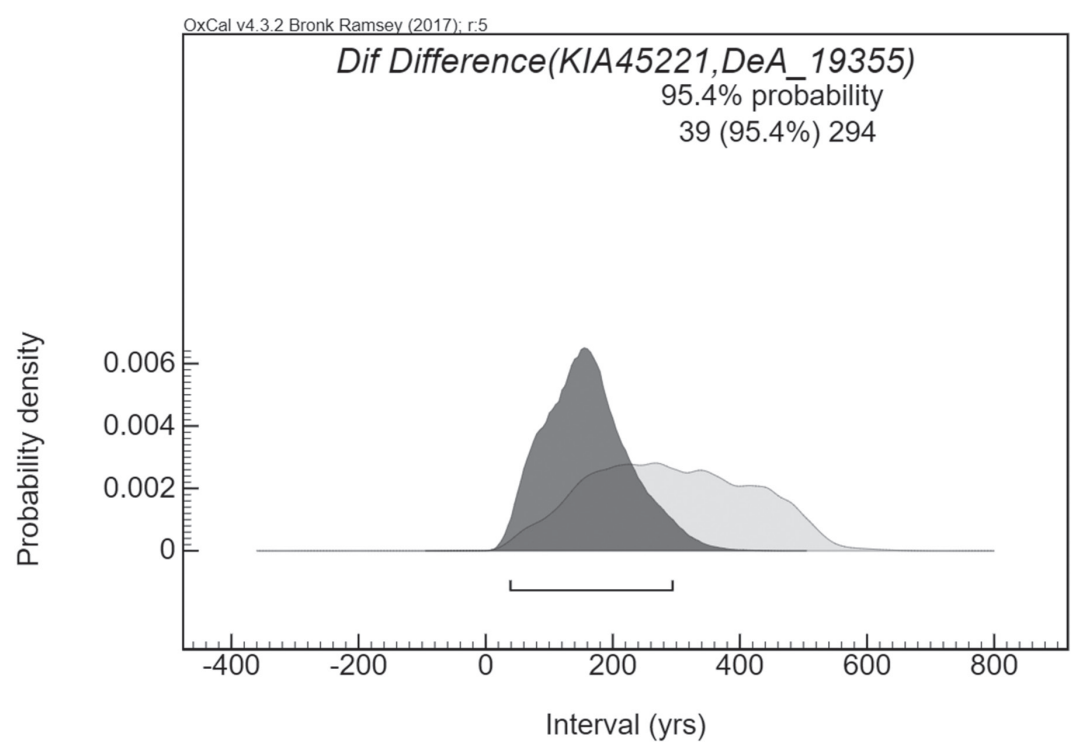

Fig. 21. Modelled age gap between Grave IV/3 of the Novo mesto-Kandija necropolis and Grave 15 of the Alsónyék cemetery

point we do not know exactly when these necropoleis ceased to be used, however there are no firm evidence for tumulus burials pertaining to the time period after the Ha D1 phase. ${ }^{125}$

What seems to be certain is that the burials of the Beremend and Szentlorinc sites and the settlement of Szajk are all indicative of a significant cultural change that had occurred in this region, too. As earlier discussed, the funerary record strongly suggests that E. Jerem's observation still holds, i.e. parallel to the proliferation of the Certosa fibulae in southern Pannonia inhumation became the dominant burial rite. ${ }^{126}$ Also, no traces of mounds above the burials came to light so far. The most striking difference with the previous period, however, is the fact that from the late $6^{\text {th }}$ century on the communities in the south-eastern part of Transdanubia began to establish exceptionally strong contacts towards the regions lying to the south, i.e. towards the Northerwest Balkans which very well might have been just as significant ${ }^{127}$ as the communication networks towards west re-emerging and regaining their significance in the valleys of the Drava and Sava rivers. ${ }^{128}$ As a result, the region under discussion became integrated into a cultural zone sketched originally by B. Teržan and M. Guštin that is commonly referred to as southern Pannonian group. ${ }^{129}$

Very shortly after the discovery of the Vinkovci-Silos graves, N. Majnarić-Pandžić brought attention to the fact that these burials assigned to the Srem group a concept put forward by M. Garašanin ${ }^{130}$ are closely related to the ones discovered near Beremend. The results of her excavations at the Vinkovci-NaMa site also supported her observation that there are clear cultural ties between the Middle Iron Age graveyards in Hungarian Baranya County and the Srem group. One of the main advantages of the concept behind the South Pannonian group is that it is perfectly capable of integrating both the south-eastern part of Transdanubia as well as the so-called Srem group. ${ }^{131}$ On the other hand it is also apt to serve as a cultural framework for it is flexible and easily adjustable both in cultural, geographical and chronological sense according to the gradually growing data, but still it might be worth envisaging more complex systems as cultural frameworks. The example of the recently discovered cemetery near SzegedKiskundorozsma is a case in point.

Ever since the uncovering of the Szentlörinc and Vinkovci burial grounds, it is obvious that in addition to the ties to the regions to the west and towards the northern Balkans the population in the southern Pannonian region maintained contacts towards the east, i.e. the population of the Vekerzug group which had imprints on both the

\footnotetext{
${ }^{125}$ METZNER-NeBELSICK 2002, 493.

${ }^{126}$ JeREM 1987; METZNER-NEBELSICK 2002.

127 MetZner-Nebelsick 2002, 493; MetZnER-Nebelsick
}

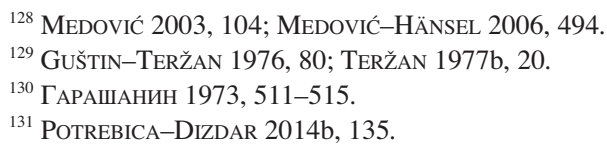

${ }^{128}$ Medović 2003, 104; Medović-Hänsel 2006, 494.

${ }^{129}$ GUŠTIN-TERŽAN 1976, 80; TERŽAN 1977b, 20

${ }^{130}$ ГАРАШАНИН 1973, 511-515.

${ }^{131}$ PotrebicA-Dizdar 2014b, 135. 
material and spiritual culture. ${ }^{132}$ The horse burials are probably the best proofs of such contacts. ${ }^{133}$ Although the cemetery of Szeged-Kiskundorozsma has not yet yielded such deposits, the overall characteristics of the burial rites and the grave goods led the authors presenting this site to conclude that the population using this graveyard at the end of the $5^{\text {th }}$ and the beginning of the next century BC was closely related in cultural sense to the peoples from southern Transdanubia and the Srem district. ${ }^{134}$ Now, while as M. Dizdar has recently pointed out the concept of the Srem group seems to be rigid especially in geographical terms, the concept of the South Pannonian Late Hallstatt group might be more capable of integrating sites of similar cultural characteristics lying even east of the Danube River ${ }^{135}$ but in this case its geographically bound definition should be discarded, as it has also been suggested by the above author. ${ }^{136}$

Interestingly, in the case of the Alsónyék cemetery there is only one single object, the earring found in Grave 1 that suggests contacts to the populations living east of the Danube River. In my view this site along with Tolna-Mözs and Paks is rather indicative of the essential role played by the Danube River in the formation of the South Pannonian Late Hallstatt cultural zone.

It is widely accepted that from the late $6^{\text {th }}$ century BC onward similarly to the Dolenjska region the western half of the Carpathian Basin also saw a period of consolidation. ${ }^{137}$ And as a result, the contacts between the populations of these regions began to strengthen again. ${ }^{138}$ There is a long-standing assumption in the research that the main routes along which the communication networks might be traced are on the one hand along the eastern fringes of the Alps, ${ }^{139}$ on the other hand along the main waterways in the South Pannonian region, chiefly in the valley of the Sava River. There is also a wide agreement that the clearest evidence for this is provided by the patterns of distribution of the Certosa type fibulae. ${ }^{140}$ The beginning of this gradual consolidation is also traceable in the area of the Sava's lower course. The earliest evidence is provided by the Banoštor find and later this trend is proven by the spectacular finds from the surroundings of Srijemska Mitrovica and Novi Banovci. One might suggest that finds such as the golden necklace, ${ }^{141}$ the Illyrian type helmet ${ }^{142}$ and the situla from Srijemska Mitrovica are in fact clear evidence for the emergence of a new elite stratum in this region. ${ }^{143}$ P. Medović and B. Hänsel claimed that both phenomena, namely the re-strengthening ties along the Sava and the social and economic upheaval in the region might have been strongly intertwined phenomena. ${ }^{144}$ This seems to be a feasible answer for why we observe the most opulent graves of southern Pannonia in the Srem region. The graves found near Beremend might be regarded as similarly prominent burials considering the silver jewellery among the grave goods. These burials can certainly be seen as evidence for the emergence of a new elite in southern Transdanubia during the same period of time. Both the grave goods and the funerary customs suggest that the members of this prominent stratum maintained strong ties with the communities living in eastern Slavonia and the Srem district which is hardly surprising given the geographical proximity between the regions mentioned. It seems to be beyond doubt that during this consolidation period the population of southern Transdanubia, naturally, gravitated towards the region of the lower course of the Sava River in cultural terms. However, it is worth mentioning the possibility that the Drave River might have played a significant role similar to that of the Sava River in the emergence of the new prominent group, i.e. set aside the apparent dominance of elements of southern origin in the burial representation, the community associated with the Beremend burials might have managed to form their own connections with western groups possibly partly along this river way. ${ }^{145}$

In spite of the larger geographical distance, the similarity seen in the elements of material and spiritual culture based on the funerary data makes it clear that the Danube River ought to have enabled the Late Hallstatt Age

132 Majnarić-PandŽić 2000, 28; Metzner-Nebelsick 2002, 418; MAJNARIĆ-PANDŽIĆ 2003, 494-495; PARE 2012, 157.

${ }^{133}$ KMEŤOVÁ 2013; KMEŤOVÁ 2017; KMEŤOVÁ 2018.

${ }^{134}$ Pilling-UjVÁRI 2012, 234.

135 This should not be surprising considering the fact, that Tibor Kemenczei has already alluded to the possibility. However, some of the evidence he lists, namely the Ártánd burials due mainly to their different chronological position are somewhat misleading in this context (KEMENCZEI 2012, Abb. 2).

${ }^{136}$ DiZDAR 2015, 51.

${ }^{137}$ TERŽAN 1998, 521; KOVAČEVIĆ 2007, 105.
${ }^{138}$ GUŠTIN-TERŽAN 1976, 80; JEREM 1981; TERŽAN 1998, 521; Dular-Tecco Hvala 2007, 232; BlečIĆ KaVur-JaŠAREviĆ 2016, 226.

139 JEREM 1981a, 212; CHYTRÁČEK et al. 2017, 196.

${ }^{140}$ JEREM 1974, 234; GUŠTIN-TERŽAN 1976, 80; TERŽAN 1977a, 362; VAsıć 1987a, 558; MEdović 2007, 89; BLEČIĆ KAVURJAŠAREVIĆ 2016, 226.

${ }^{141}$ BrunŠMid 1902, S1. 36; Dizdar-PotrebiCA 2014a, 153.

${ }^{142}$ TERŽAN 1995, 116; VASIĆ 2010, Pl. 6,4.

${ }^{143}$ Babić-Palavestra 1999, 30; Luustina 2010, 66.

144 MEDOVIĆ-HÄNSEL 2006, 493.

145 KovaČEvić 2008, 67. 
to the one found in Szentlörinc might represent entirely different phenomena in terms of burial customs of the Middle Iron Age population in the southwestern part of the Carpathian Basin would be misleading.

The recently discovered cemetery near Alsónyék and the re-evaluation of the long-known sites in southern Transdanubia reveal that instead of two separate phenomena the funerary evidence suggests that both groups are part of a complex system which is in need for further investigations. The fact that this cemetery dated to the $5^{\text {th }}$ century BC shows somewhat diverse burial rites similar to the case of the Szentlörinc graveyard. It is also worth highlighting that there is no clear-cut chronological separation between the Szentlörinc cemetery and the 'Beremend-type' burials, on the contrary, the stray finds of the Beremend site clearly suggest that this hitherto insufficiently investigated burial ground is at least partially overlapping with the Szentlörinc cemetery in chronological terms. The Alsónyék cemetery provides the first evidence that there are burial grounds with both 'Beremend-type' burials and graves dated to the second phase of the Szentlörinc cemetery, i.e. to the latest decades of the $5^{\text {th }}$ centuries $\mathrm{BC}$. In other words, it is the first time the graves with rich assemblages consisting of astragal belts, Certosa fibulae and glass paste beads appear in a well-documented context that also makes it possible to draw conclusions about the social relations.

In 1999 S. Babić and A. Palavestra put forward two possible scenarios describing why the 'Beremend-type' burials seem to dominate the funerary record of the Late Hallstatt Age in southern Pannonia. In their view, it is either the result of a universal affluence within the society or simply the result of the current state of research, in other words only burials of the higher social strata's members have been identified. The example of the Alsónyék cemetery and the partial simultaneity of the younger instances of the 'Beremend-type' burials and the Szentlörinc cemetery's first internments strongly suggest that the differences in the composition of grave assemblages might encode some kind of social differentiation, though, as the above authors have already pointed out, ${ }^{156}$ this could not have been as articulated as that observed in the case of the Eastern Hallstatt Zone in the preceding centuries.

Finally, it is worth addressing the question of the graves equipped with weapons. One of the most significant factors that made the Szentlörinc cemetery exceptional among the Late Hallstatt burial sites in southern Transdanubia was the relatively large number of graves with spearheads or battle knifes among their grave goods. In contrast, there was no such burial associated with 'Beremend-type' graves in the aforementioned region. This bears great significance given the fact that while the 'Beremend-type' burials suggest the existence of strong cultural ties along the Danube and a relatively apparent standardization of the composition of grave goods among the communities connected by such ties. By contrast, the warrior graves of the Szentlőrinc cemetery, according the B. Teržan, gravitate toward the area of today's northwest Bosnia based on the most characteristic elements of warrior equipment. ${ }^{157}$ Grave 15 of the Alsónyék cemetery reveals that the concepts behind the composition of the warrior equipment seen in Sanski most, Donja dolina and Szentlörinc could have had penetrated the area of southern Transdanubia before the use of the Szentlörinc cemetery began, and this might shed some light on the complex ways the communities in the southwestern part of the Carpathian Basin might have interacted with each other. Of course, this and several other aspects of the funerary customs and cultural relations of the Late Hallstatt Age in southern Transdanubia and beyond still need more thorough and meticulous investigations.

\section{ACKNOWLEDGEMENTS}

I would like to express my gratitude towards János Gábor Ódor for allowing me to work with the material recovered from the Alsónyék cemetery. I am also indebted to Márta Vizi, Attila Czövek and Antal Csiszér for their enormous help during my visits to the Mór Wosinszky Museum. I am also deeply grateful to Csilla Gáti for giving me access to the finds of the Beremend burials and the Szentlörinc cemetery. Also, I am deeply grateful for Zoltán Czajlik's guidance and invaluable advices.

This research was supported by the ÚNKP-18-2 New National Excellence Program of the Ministry of Human Capacities.

${ }^{156}$ BABIĆ-PALAVESTRA 1999, 30.
${ }^{157}$ TERŽAN $1977 b, 14$ 
REFERENCES

АнъЕЛИЋ 2017

BABIĆ-PALAVESTRA 1999

BaLÁzs KovÁcs 2015

BENCS-DÁVID 2016

BENDE 2003

BRUNŠMID 1902

DIZDAR 2010

DIZDAR 2015

DiZDAR 2019

DIZDAR-TONC 2018

DJUKNIĆ-JOVANOVIĆ 1965

DOBIAT 1980

DULAR 1982

Dular-Tecco Hvala 2007

FILIPOVIĆ-MLAdENOVIĆ 2017

GAÁL 2001

GALÁNTHA 1985

ГАРАШАНИН 1973

GÁTI 2009

GÁTI 2014

GAVRANOVIĆ 2011

GUŠTIN-TERŽAN 1975
= Д. АнъЕлић: Налази старијег гвозденог доба у околини Новог Сада (Artefacts from the Early Iron Age in the vicinity of Novi Sad). GPSKV 30 (2017) 32-47.

$=$ S. BABIĆ-A. Palavestra: Northern Serbia in the second half of the first millenium BC - Socioeconomic aspects. In: Le Djerdap/Les portes de Fer à la deuxieme moitie du premiern millenaire av. J. Ch. jusqu'aux guerres daciques. Kolloquium in Kladovo-Drobeta-Turnu Severin (SeptemberOctober 1998). Ed.: M. Vasić. Jugoslawisch-Rumänische Kommission für die Erforschung der Region des Eisernen Tores 3. Beograd 1999, 28-33.

= S. BALÁzs KovÁcs: A régi Sárköz (Das alte Sárköz). WMMÉ 36 (2015) 217-298.

= J. BENCS-F. DÁviD: „Merre a Dráva vize öntözi Pannoniát”. Drávaszabolcs nyolc évszázada ('Where Pannonia is watered by the Drava River'. Eight Centuries of Drávaszabolcs). Drávaszabolcs 2016.

= L. BENDE: Szkíta kori temető Algyőn (Cemetery from the Scythian period at Algyő). In: Régészeti Kutatások Magyarországon 2001. Ed.: J. Kisfaludi. Budapest 2003, 63-78.

= J. BRUNŠMID: Prethistorijski predmeti iz Srijemske Županije (Prehistoric objects from Srem County). VAMZ 6/1 (1902) 68-86.

= M. DIZDAR: Kantharoi of Autochthonous-"Pannonian" origin from the La Tène culture cemetery in Zvonimirovo, Croatia. In: Iron Age Communities in the Carpathian Basin. Proceedings of the International Colloquium from Târgu Mureș 9-11 October 2009. Ed.: S. Berecki. Bibliotheca Mvsei Marisiensis, Seria archaeologica 2. Cluj-Napoca 2010, 297-307.

= M. DizDAR: Late Hallstatt female frave from Belišće. A group of Late Hallstatt finds in the Lower Drava Valley. In: Beiträge zur Hallstattzeit am Rande der Südostalpen. Akten des 2. Wildoner Fachgespräches am 10. und 11. Juni 2010 in Wildon/Stmk. Hrsg.: Ch. Gutjahr, G. Tiefengraber. IntArch - Arbeitsgemeinschaft, Symposium, Tagung, Kongress 19. Rahden/Westf. 2015, 45-60.

$=$ M. DizDaR: New Late Hallstatt finds from the Vinkovci Region (Eastern Croatia): A contribution to the ctudy of impacts from the Balkans to the southeastern Carpathian Basin. In: Papers in Honour of Rastko Vasić $80^{\text {th }}$ Birthday - Зборник радова у част 80 г. живота Растка Васића. Eds: V. Filipović, A. Bulatović, A. Kapuran. Belgrade 2019, 319-344.

= M. DizDAR-A. Tonc: Not just a belt: Late Iron Age female costume in the south-east Carpathian Basin. Starinar 68 (2018) 47-63.

= M. DuUKNIĆ-B. JovANović: Illyrian princeli necropolis at Atenica. AI 6 (1965) 1-26.

= C. DoBIAT: Das hallstattzeitliche Gräberfeld von Kleinklein und seine Keramik. SchSt Bh 1. Graz 1980.

= J. DulaR: Halštatska keramika v Sloveniji (Die Grabkeramik der älteren Eisenzeit in Slowenien). Dela 1. razreda SAZU 23. Ljubljana 1982.

= J. Dular-S. Tecco Hvala: South-eastern Slovenia in the Early Iron Age: settlement-economy-society - Jugovzhodna Slovenija v starejši želenzni dobi: poselitev, gospodarstvo, družba. Opera Instituti Archaeologici Sloveniae 12. Ljubljana 2007.

= V. Filipović-O. Mladenović: Prilog proučavanju članaka astragalnih pojaseva sa teritorije centralne i jugoistočne Evrope [Contribution to the study of astragal belt segments from the territory of Central and Southeastern Europe]. Prilozi Instituta za arheologiju u Zagrebu 34 (2017) 143-184.

= A. GAÁL: Késő vaskori sír az S-9-es út területéről (Späteisenzeitliches Grab vom Gebiet der Autostraße S9). In: Tolna megye évszázadai a régészet tükrében. Hrsg. : A. Gaál. Szekszárd 2001, 27-30.

= M. GALÁNTHA: Előzetes jelentés a Sándorfalva-eperjesi szkíta kori temető feltárásáról (Vorbericht über die Ausgrabungen des Skythenzeitlichen Gräberfeldes in Sándorfalva-Eperjes). MFMÉ 1982_ 83/1 (1985) 115-128.

= М. ГАРАшАнин: Праисторија на тлу Сп. Србије (The Prehistory of the Territory of the Socialist Republic of Serbia). Београд 1973.

= Cs. GÁtı: A szajki (Baranya megye) koravaskori telep kulturális kapcsolatai (Cultural contacts of the Early Iron Age settlement at Szajk, Baranya County). In: M $\Omega$ MO $\Sigma$ VI. Öskoros Kutatók VI. Összejövetelének konferenciakötete. Nyersanyagok és kereskedelem, Kőszeg, 2009. március 19_ 21. Ed.: G. Ilon. A debreceni Déri Múzeum kiadványai. Szombathely 2009, 65-77.

= Cs. GÁtI: On the crossroads of cultures. Cultural and trade connections of the site of Szajk in South Transdanubia. In: Iron Age Crafts and Craftsmen in the Carpathian Basin. Proceedings of the International Colloquium from Târgu Mureş 10-13 October 2013. Ed.: S. Berecki. Bibliotheca Mvsei Marisiensis, Seria archaeologica 7. Târgu Mureş 2014, 115-138.

= M. Gavranović: Die Spätbronze- und Früheisenzeit in Bosnien. 1. UPA 195. Bonn 2011

= M. Guštin-B. TeRŽAn: Malenškova gomila v Novem mestu (The Malenškova gomila in Novo mesto). AV 26 (1975) 188-202. 
GUŠTIN-TERŽAN 1977

HOERNES 1901

HoRVÁTH 2001

HoRVÁTH 2015

JÁKY 2016

JÁKY 2017

JEREM 1968

JEREM 1973

JEREM 1974

JEREM 1975

JEREM 1981a

JEREM 1981b

JEREM 1987

JEREM 1996

JoVANOVIĆ 1998

KÁROLYI 1973

KeMENCZEI 2009

KILIAN 1975

KMEŤOvÁ 2013

KMEŤOvÁ 2017

KMEŤOvÁ 2018

КолЕДИн 2012
= M. GuŠTIN-B. TERŽAN: Beiträge zu den vorgeschichtlichen Beziehungen zwischen dem Südostalpengebiet, dem nordwestlichen Balkan und dem südlichen Pannonien im 5. Jahrhundert. In: Ancient Europe and the Mediterranean: Studies presented in honour of Hugh Hencken. Ed.: V. Markotic. Warminster 1977, 77-89.

= M. HoERNES: Funde verschiedener Alterstufen aus dem westlichen Syrmien. MPK I/5 (1901) 265-289.

= A. HorvÁtH: Szabadszállás-Józan szkítakori temető (Scythian Age cemetery at SzabadszállásJózan). In: Hatalmasok viadalokban. Az Alföld szkíta kora. Ed.: P. Havassy. Gyulai katalógusok 10. Gyula 2001, 95-100.

= L. HoRVÁTH: Középső vaskori öntőformák Alsópáhokról (Middle Iron Age moulds from Alsópáhok). ArchÉrt 140 (2015) 229-255.

= A. JÁKY: Periodization of the settlement of Balatonboglár-Berekre-dülő in the Iron Age. In: Iron Age Chronology in the Carpathian Basin. Proceedings of the International Colloquium from Târgu Mureş, 8-10 October 2015. Ed.: S. Berecki. Bibliotheca Mvsei Marisiensis, Seria archaeologica 12. Cluj-Napoca 2016, 97-118.

= A. JÁKY: A remarkable Early Iron Age grave from Szólád-Kertek mögött. In: Sedem decénií Petra Romsauera. Mimoriadne číslo časopisu venované životnému jubilee prof. Petra Romsauera. Ed.:

J. Hečková. Studia Historica Nitriensia 21 (2017) Supplementum. Nitra 2017, 381-390.

= E. JerEM: The Late Iron Age cemetery of Szentlörinc. ActaArchHung 20 (1968) 159-208.

$=$ E. JEREM: Zur Geschichte der späten Eisenzeit in Transdanubien. Späteisenzeitliche Grabfunde von Beremend. ActaArchHung 25 (1973) 65-86.

= E. JEREM: Handelsbeiehungen zwsichen der Balkanhalbinsel und dem Karpatenbecken im IV. und V. Jahrhundert v. u. Z. In: Symposium zu Problemen der jüngeren Hallstattzeit in Mitteleuropa. Hrsg.: B. Chropovský. Bratislava 1974, 229-242.

= E. JEREM: Vaskori kutatások a Dél-Dunántúlon (Iron Age research in South Transdanubia). SMK 2 (1975) 269-274.

= E. JEREM: Südliche Beziehungen einiger hallstattzeitlichen Fundtypen Transdanubiens. MatSADJ 19 (1981) 201-220.

= E. JEREM: Zur Späthallstatt- und Frühlaténezeit in Transdanubien. In: Die Hallstattkultur. Bericht über das Symposium in Steyr 1980 aus Anlaß der internationalen Ausstellung des Landes Oberösterreich. Hrsg.: C. Eibner, A. Eibner. Linz 1981, 105-136.

= E. JEREM: Die ältesten Körperbestattungen im Osthallstattkreis. MUAG 37 (1987) 91-101.

= E. JEREM: Zur Ethnogenese der Ostkelten - Späthallstatt- und frühlaténezeitliche Gräberfelder zwischen Traisental und Donauknie. In: Die Kelten in den Alpen und an der Donau: Akten des Internationalen Symposiums, St. Pölten, 14.-18. Oktober 1992. Hrsg.: E. Jerem, A. Krenn-Leeb, J.-W. Neugebauer, O. H. Urban. Archaeolingua: Studien zur Eisenzeit im Ostalpenraum. Budapest 1996, 91-110.

= M. JovANOVIĆ: Astragalni pojasevi na području centralnog Balkana i jugoistočne Evrope (Astragaloid belts in the region of the Centrals Balkans and Southeast Europa). RMV 40 (1998) 39-96.

= Z. KÁROLYI: A Balaton és vízrendszere (Lake Balaton and its water system). In: A magyar vízszabályozás története (The History of Hungarian Water Regulations). Ed. D. Ihrig. Budapest 1973, 249-271.

$=$ T. KEMENCZEI: Studien zu den Denkmälern skythisch geprägter Alföld-Gruppe. IPH 12. Budapest 2009.

= K. KILIAN: Trachtzubehör der Eisenzeit zwischen Ägäis und Adria. PZ 50 (1975) 9-140.

= P. KMEŤOvÁ: "Masters of horses" in the West, "horse breeders" in the East? On the significance and position of the horse in the Early Iron Age communities of the Pannonian Basin. In: Interpretierte Eisenzeiten. Fallstudien, Methoden, Theorie. Tagungsbeiträge der 5. Linzer Geschpräche zur interpretativen Eisenzeitarchäologie. Hrsg.: R. Karl, J. Leskovar. Studien zur Kulturgeschichte von Oberösterreich 37. Linz 2013, 247-258.

= P. KMEŤOvÁ: Contacts between the Late Hallstatt groups of the Pannonian Basin, the south-east Alpine Hallstatt region and ancient Veneti from the perspective of horse burials In: Inter-Regional Contacts during the First Millennium B.C. in Europe. Eds: M. Trefný, B. Jennings. Hradec Králové 2017, 92-117.

= P. KMEŤOVÁ: 'And four strong-necked horses he threw swiftly on the pyre...' On human-horse relationship in the Early Iron Age Central Europe from the perspective of interregional contacts. In: EY $\triangle \mathrm{AIM} \Omega$ N. Studies in Honour of Jan Bouzek. Eds: P. Pavúk, V. Klontza-Jaklová, A. Harding. Prague 2018, 267-290.

= J. КолЕдин: О једном новијем налазу из гвозденог доба у Срему (About a new Iron Age site in Srem County). Strarinar 62 (2012) 107-112. 
KOROŠEC 1943

KOVAČEVIĆ 2007

KovaČEVIĆ 2008

KOVAČEVIĆ 2019

KoZUBOVÁ 2013

LJUŠTINA 2010

MAJNARIĆ-PANDŽIĆ 1973

MAJNARIĆ-PANDŽIĆ 2003

MAJNARIĆ-PANDŽIĆ 2009

MANO-ZISI-PoPOVIĆ 1971

MARIĆ 1964

MARIJAN 1986

Marton-RegenYe 2005

MÁRTON 1933

Medović 2003

Medović 2007

MetZNER-NebELSICK 2002

METZNER-NeBELSICK 2017

ПАЛАВЕСТРА 1984

PÁRDUCZ 1955

PARE 2012

PARZINGER 1989

PATEK 1993

PETRIĆ et al. 2019
= J. KOROŠEC: Noviji neobjavljeni predmeti predpoviestne zbirke. Nekoliko novih nalaza sa gradine "Grad" iznad Semizovca (New unpublished finds of the Prehistoric Collection. Some new finds from the Grad hillfort near Semizovac). GZM 54 (1943) 51-59.

= S. KovAČEVIĆ: Karakteristični nalazi kasnohalštatskog naselja u Zbelavi kod Varaždina i fibula tipa Velem (Characteristic finds from the late Hallstatt settlement at Zbelava near Varaždin and a Velemtype fibula). Prilozi Instituta za arheologiju u Zagrebu 24 (2007) 89-112.

= S. KovAČEvIĆ: Osvrt na strukturu i keramičku proizvodnju kasnohalštatskog naselja u Zbelavi kod Varaždina (A look at the structure and ceramic production of the late Hallstatt settlement in Zbelava near Varaždin). Prilozi Instituta za arheologiju u Zagrebu 25 (2008) 47-80.

$=$ S. KovAČEvić: Architecture of power or demise: Gigantic burial mounds of Podravina as parts of the Early Iron Age landscape. The Iron-Age-Danube project in the Plitvica-Bednja Rivers Basin (NW Croatia). In: Early Iron Age Landscapes of the Danube Region. Eds: M. Črešnar, M. Mele. Graz-Budapest 2019, 109-140.

= A. KozuBovÁ: Pohrebiská vekerzugskej kultúry v chotíne na juhozápadnom Slovensku (Die Gräberfelder der Vekerzug-Kultur in Chotín in der Südwestslowakei). Dissertationes archaeologicae Bratislavenses 1. Bratislava 2013.

= M. LuUŠTINA: The Late Hallstatt communities in the Serbian part of the Danube Basin. In: Iron Age Communities in the Carpathian Basin. Proceedings of the International Colloquium from Târgu Mureş 9-11 October 2009. Ed.: S. Berecki. Bibliotheca Mvsei Marisiensis, Seria archaeologica 2. Cluj-Napoca 2010, 59-78.

= N. MAJNARIĆ-PANDŽIĆ: Vinkovci kod Silosa - kasnohalštatski grobovi (Vinkovci-Silos - Late Hallstatt Age graves). AP 15 (1973) 39-40.

= N. MAJNARIĆ-PANDŽIĆ: Ein späthallstattzeitliches Gräberfeld in Vinkovci (Nordostkroatien) und das Problem eines neuen Phänomens der Pferdausstattung in diesem Gebiet. Germania 81 (2003) 481-511.

$=$ N. MajnARIĆ-PANDŽIĆ: On the south Pannonian population in the Late Iron Age. In: Keltske študije. II. Studies in Celtic Archaeology. 2.: Papers in honour of Mitja Guštin. Eds: G. Tiefengraber, B. Kavur, A. Gaspari. Protohistoire Européenne 11. Montagnac 2009, 235-246.

= D. Mano-Zisi-L. Popović: Der Fund von Novi Pazar (Serbien). BRGK 50 (1971) 191-208.

= Z. MARIĆ: Donja dolina. GZM BiH 19 (1964) 5-128.

= B. MARIJAN: Zajednička grobnica željeznog doba iz Vašarovina kod Livna (Iron Age mass grave from Vašarovina near Livna). GZM BiH Arheologija 40/41 (1985/1986) 23-38.

= E. Marton-J. Regenye: A fortified site from the Late Bronze-Late Iron Age at Lake Balaton in Tihany-Óvár: A rescue excavation in Hungary, May 2000. In: $14^{\mathrm{e}}$ Congrès UISPP, Université de Liège, Belgique, 2-8 septembre 2001. Section 12: Âge du Fer en Europe - The Iron Age in Europe. BAR IntSer 1378. Oxford 2005, 45-52.

= L. MÁRTON: A korai La Tene-kultúra Magyarországon [Die Frühlatenezeit in Ungarn]. ArchHung 11. Budapest 1933.

= P. Medović: Bestattungen in der älteren Eisenzeit im Gebiet der Bosut-Gruppe. In: Sahranjivanje u bronzano i gvozdeno doba: simpozijum, Čačak, 4-8. Septembar 2002. Eds: N. Bojović, M. Vasić, R. Vasić. Čačak 2003, 101-107.

= P. Medović: Stubarlija - Nekropola naselja Feudvar kod Mošorina (Bačka) (Stubarlija - Das Gräberfeld der Siedlung Feudvar bei Mošorin, Bačka). Posebna izdanja/Muzej Vojvodine 20. Novi Sad 2007.

= C. MetzneR-Nebelsick: Der „Thrako-Kimmerische“ Formenkreis aus der Sicht der Urnenfelderund Hallstattzeit im südöstlichen Pannonien. Vorgeschichtliche Forschungen 23. Leidorf 2002.

= C. Metzner-Nebelsick: At the crossroads of the Hallstatt East. In: Connecting Elites and Regions. Perspectives on contacts, relations and differentiation during the Early Iron Age Hallstatt C period in Northwest and Central Europe. Eds: R. Schumann, S. Vaart-Verschoof. Leiden 2017, 349-379.

= А. ПАЛАвЕСтРА: Кнежевски гробови старијег гвозденог доба на централном Балкану (Princely Tombs during the Early Iron Age in the Central Balkans). Београд 1984.

= M. PÁRDUCZ: Le cimetiere halstattien de Szentes-Vekerzug III. ActaArchHung 6 (1955) 1-19.

$=\mathrm{CH}$. PARE: Eastern relations of Early Celtic art. In: Kunst und Kommunikation. Zentralisierungsprozesse in Gesellschaften des europäischen Barbarikums im 1. Jahrtausend v. Chr. Hrsg. : Ch. Pare. Mainz 2012, 153-178.

= H. PARZINGER: Chronologie der Späthallstatt- und Frühlatène-Zeit: Studien zu Fundgruppen zwischen Mosel und Save. Quellen und Forschungen zur prähistorischen und provinzialrömischen Archäologie 4. Weinheim 1989.

= E. PATEK: Westungarn in der Hallstattzeit. Quellen und Forschungen zur prähistorischen und provincialrömischen Archäologie 7. Weinheim 1993.

= H. Petrić-A. E. TAmás- D. Lóczy: Flood history and river regulation. In: The Drava River. Environmental Problems and Solutions. Ed.: D. Lóczy. Cham 2019, 105-124. 
Pilling-UJVÁRI 2012

PoPOVIĆ 1981

PotrebicA 2003

PotrebiCA-DizdAR $2014 a$

PotrebiCA-DizDAR 2014b

RADIMSKY 1895

REBAY 2006

RASSMANN et al 2015

ŠIMEK 1998

СРЕЈовИТ-ВУКАДИН 1988

Soós in press

SZABÓ 2012

SZILÁGYI 1992

TASIĆ 2004

Tecco Hvala 2012

TERŽAN 1977a

TERŽAN 1977b

TERŽAN 1990

TERŽAN 1998

TERŽAN-ČREŠNAR 2014

ТрАјковић 2008

TRUHELKA 1904

ВАСИљЕВИТ 1976

VASIĆ 1971

VASIĆ 1977
= Z. PILling-F. UjVÁRI: Iron Age settlement and cemetery from Szeged-Kiskundorozsma. In: Iron Age Rites and Rituals in the Carpathian Basin. Proceedings of the International Colloquium from Târgu Mureş 7-9 October 2011. Ed.: S. Berecki. Bibliotheca Mvsei Marisiensis, Seria archaeologica 5. Târgu Mureş 2012, 217-248.

= D. Popović: Keramika starijeg Gvozdenog doba u Sremu (Die Keramik der älteren Eisenzeit in Syrmien). Fontes archaeologia Iugoslaviae 4. Beograd 1981.

$=$ H. PotrebiCA: Požeška kotlina i Donja Dolina u komunikacijskoj mreži starijeg željeznog doba (The Požega Valley and Donja Dolina in communication network of the Early Iron Age). OA 27 (2003) 217-242.

$=$ H. Potrebica-M. Dizdar: Late Hallstatt and Early La Tène gold and silver beads in Southeast Pannonia. In: Celtic Art in Europe - Making Connections. Essays in honour of Vincent Megaw on his 80th birthday. Eds: Ch. Gosden, S. Crawford, K. Ulmschneider. Oxford 2014, 152-158.

$=$ H. PotrebiCA-M. DizDAR: Changing identities of the Iron Age communities of Southern Pannonia. In: Fingerprinting the Iron Age. Approaches to Identity in the European Iron Age. Integrating SouthEastern Europe into the Debate. Eds: C. N. Popa, S. Stoddart. Oxford 2014, 123-141.

= W. RADIMSKY: Die Nekropole von Jerezine in Pritoka bei Bihać. WMBH 3 (1895) 60-218.

$=$ K. REBAY: Das hallstattzeitliche Gräberfeld von Statzendorf in Niederösterreich. Möglichkeiten und Grenzen der Interpretation von Sozialindexberechnungen. UPA 135. Bonn 2006.

= K. Rassmann-C. MischKa-M. Furholt-R. Ohlrau-K. Radloff-K. Winkelmann-G. SerlegiT. Marton-A. OszTÁs-K. Oross-E. BÁNFFY: Large scale geomagnetic prospection on neolithic sites in Hungary. 1. Hungarian Archaeology 2015 Spring, 1-8.

http://files.archaeolingua.hu/2015TA/Rassmann_E15TA.pdf

$=$ M. ŠIMEK: Ein Grabhügel mit Pferdebestattung bei Jalžabet, Kroatien. In: Das Karpatenbecken und die osteuropäische Steppe. Hrsg.: B. Hänsel, J. Machnik. Prähistorische Archäologie in Südosteuropa 12. Südosteuropa-Schriften 20. Leidorf 1998, 493-510.

= Д. Срејовит-О. ВукАдин: Благо из Крушевице (Le tresor de Kruševica). Рашка Баштина 3 (1988) 7-18.

= B. Soós: Middle Iron Age Cemetery from Alsónyék, Hungary. DissArch III/8, in press.

= M. Szabó: Celtes et Pannons dans le sud-est de la Transdanubie. ActaArchHung 63 (2012) 351-366.

= J. Gy. SZILÁGYI: Transdanubien und Italien im 6.-5. Jh. In: Etrusker nördlich von Etrurien. Etruskische Präsenz in Norditalien und nördlich der Alpen sowie ihre Einflüsse auf die einheimischen Kulturen. Akten des Symposions von Wien-Schloß Neuwaldegg 2.-5. Oktober 1989. Hrsg.: L. Aigner-Foresti. Wien 1992, 219-234.

$=$ N. TASIć: Historical picture of development of Early Iron Age in the Serbian Danube basin. Balcanica 35 (2004) 7-22.

$=\mathrm{S}$. Tecco Hvala: Magdalenska gora. Družbena struktura in grobni rituali železnodobne skupnosti - Magdalenska gora. Social Structure and Burial Rites of the Iron Age Community. Opera Instituti Archaeologici Sloveniae 26. Ljubljana 2012.

= B. TERŽAN: Certoska fibula [Die Certosafibel]. AV 27 (1977) 317-536.

= B. TERŽAN: O horizontu bojevniških grobov med Padom in Donavo v 5. in 4. stol. pr. n. št. (Horizon of warrior tombs found in the fifth and fourth centuries B.C. in the territory between the Po and the Danube). In: Keltske študije. Ed.: M. Guštin. Posavski muzej Brežice 4. Brežice 1977, 9-21.

= B. TERŽAn: Starejša železna doba na slovenskem Štajerskem - The Early Iron Age in Slovenian Styria. KiM 25. Ljubljana 1990.

= B. TERŽAN: Auswirkungen des skythisch geprägten Kulturkreises auf die hallstattzeitlichen Kulturgruppen Pannoniens und des Ostalpenraumes. In: Das Karpatenbecken und die osteuropäische Steppe. Hrsg. : B. Hänsel, J. Machnik. Prähistorische Archäologie in Südosteuropa 12. SüdosteuropaSchriften 20. Leidorf 1998, 511-560.

= B. TERŽAN-M. ČREŠNAR: Poskus absolutnega datiranja starejše železne dobe na Slovenskem (Attempt at an absolute dating of the Early Iron Age in Slovenia). In: Absolutno datiranje bronaste in železne dobe na Slovenskem - Absolute Dating of the Bronze and Iron Ages in Slovenia. Eds: B. Teržan, M. Črešnar. KiM 40. Ljubljana 2014, 703-724.

= Д. ТрАлковић: Ђепфелд. некрополе старијег гвозденог доба код Дорослова (Đepfeld: Early Iron Age Necropolis at Doroslovo). Sombor 2008.

= Č. TruhElKA: Der vorgeschichtliche Pfahlbau im Savebette bei Donja Dolina. WMBH 9 (1904) 3-170.

= М. ВАсиљЕВић: Налази старијег гвозденог доба у Шапцу (Les trouvailles de l'âge du fer ancien à Šabac). Старинар 27 (1976) 167-174.

= R. VAsić: The openwork belts and the Early Iron Age chronology of the northern Balkans. AI 12 (1971) 1-13.

= R. VASIĆ: The Chronology of the Early Iron Age in Serbia. BAR SuppSer 31. Oxford 1977. 
VASIĆ $1987 \mathrm{a}$

VASIĆ 1987

VASIĆ 1988

VASIĆ 1989

VASIĆ 1999

VINSKI-VINSKI-GASPARINI 1962

WOSINSKY 1888
$=$ R. VASIĆ: Sremska grupa zapadnobalkanskog kompleksa (The Srem group of the West Balkan complex). In: Praistorija jugoslavenskih zemalja. V.: Željezno doba. Ed.: S. Gabrovec. Ljubljana 1987, 555-558.

= R. VAsić: Prilog proučavanju lučnih fibula sa pravougaonom nogom na Balkanu (Beitrag zur Erforschung der Bogenfibeln mit viereckiger Fussplatte auf dem Balkan). AV 38 (1987) 41-68.

= R. VASIĆ: Ein Beitrag zur Chronologie der Späthallstattzeit im Sremgebiet. In: Gomolava. Chronologie und Stratigraphie der vorgeschichtlichen und antiken Kulturen der Donauniederung und Südosteuropas. Hrsg.: N. Tasić, J. Petrović. Internationales Symposium Ruma 1986. Gomolava 1. Novi Sad 1988, $169-176$.

$=$ R. VASIĆ: Jedan prilog proucavanju Sremske grupe (Une contribution a l'étude du Grupe de Syrmie). GCBI 25 (1989) 103-113.

= R. VAsIĆ: Die Fibeln im Zentralbalkan (Vojvodina, Serbien, Kosovo und Makedonien). PBF XIV/12. Stuttgart 1999.

= Z. VINSKI-K. VINSKI-GASPARINI: O utjecajima istočno-alpske Halštatske kulture i balkanske ilirske kulture na slavonsko-srijemsko Podunavlje [On the influences of the Eastern Alpine Hallstatt culture and the Illyrian culture of the Balkans on the Slavonian-Syrmian Danube region]. ARR 2 (1962) 263-293.

= M. WosInSKY: Das prähistorische Schanzwerk von Lengyel, seine Erbauer und Bewohner. Budapest 1888 .

Open Access. This is an open-access article distributed under the terms of the Creative Commons Attribution 4.0 International License (https:// creativecommons.org/licenses/by/4.0), which permits unrestricted use, distribution, and reproduction in any medium, provided the original author and source are credited, a link to the CC License is provided, and changes - if any - are indicated. (SID_1) 
